\title{
Stipo pulcherrimae-Festucetalia pallentis Pop 1968 of calcareous petrophytic steppes in Ukraine
}

\author{
Yakiv Didukh $^{1}$ (1), Iuliia Vasheniak ${ }^{2, *(1)}$ \& Olga Chusova ${ }^{1}$ (1)
}

Key words: calcareous bedrocks, petrophytic steppes, Stipo pulcherrimae-Festucetalia pallentis, syntaxonomy, Ukraine, vegetation classification.

Ključne besede: apnenčasta podlaga, petrofitska stepa, Stipo pulcherrimae-Festucetalia pallentis, sintaksonomija, Ukrajina, klasifikacija vegetacije.
Received: 6. 8. 2020

Revision received: 21.11 .2020

Accepted: 4. 1. 2021

\begin{abstract}
Nine hundred and eight-nine relevés from calcareous petrophytic steppes in Ukraine and its adjacent territories were assessed with the help of expert systems to determine the syntaxonomic affiliation of the plant communities at class and order levels. At least 488 relevés belonging to the class Festuco-Brometea were analyzed using the TWINSPAN algorithm, and 8 distinctive clusters were obtained, recognized as alliances of the order Stipo pulcherrimae-Festucetalia pallentis. A new alliance, Bromopsido cappadocicae-Asphodelinion tauricae, was ascribed to the Crimean Mountains and the presence of two alliances, Diantho lumnitzeri-Seslerion albicantis and Genisto tetragonae-Seselion peucedanifoliae, was confirmed as new for this vegetation in Ukraine. Unlike in the Pannonian Basin, Bromo pannonici-Festucion csikhegyensis alliance communities mentioned in the literature do not occur in Ukraine. Centaureo carbonatae-Koelerion talievii has been provisionally transferred from Festucetalia valesiacae to the order Stipo pulcherrimae-Festucetalia pallentis. Furthermore, we distinguished alliances by their geographic locations and their climatic (thermoregime, cryoregime, light in communities) and edaphic (carbonate content, salinity, and acidity) features.

Izvleček

S pomočjo ekspertnih sistemov smo ovrednotili devetsto oseminosemdeset popisov apneniške petrofitske stepe v Ukrajini in sosednjih območjih in tako določili sintaksonomsko pripadnost teh rastlinskih združb na nivoju razreda in reda. Vsaj 488 popisov, ki pripadajo razredu Festuco-Brometea, smo analizirali s TWINSPAN algoritmom in dobili 8 ločenih klastrov, ki jih lahko opredelimo kot zveze reda Stipo pulcherrimae-Festucetalia pallentis. V Krimskem gorovju smo opisali novo zvezo Bromopsido cappadocicae-Asphodelinion tauricae in potrdili novo pojavljanje dveh zvez v vegetaciji Ukrajine: Diantho lumnitzeri-Seslerion albicantis in Genisto tetragonae-Seselion peucedanifoliae. V nasprotju s Panonskim bazenom združbe zveze Bromo pannonici-Festucion csikhegyensis ne uspevajo v Ukrajini, kot se navaja v literaturi. Zvezo Centaureo carbonatae-Koelerion talievii smo začasno premestili iz reda Festucetalia valesiacae v red Stipo pulcherrimae-Festucetalia pallentis. Nadalje smo zveze ločili glede na geografski položaj, klimatske (toplota, kriorežim, svetloba) in edafske (vsebnost karbonatov, slanost in kislost) značilnosti.
\end{abstract}

\footnotetext{
1 M. G. Kholodny Institute of Botany NAS of Ukraine, Tereshchenkivska Str., 2, MSP-1, Kyiv, 01601, Ukraine. E-mail: ya.didukh@gmail.com, olgachusova28@gmail.com

2 Vasyl' Stus Donetsk National University, 500th Anniversary Str., 21, Vinnytsia, 21000, Ukraine. E-mail: arrhenatherum@gmail.com

* Corresponding author
} 


\section{Introduction}

Calcareous petrophytic steppes are characterized by a significant occurrence of chamaephyte and hemicryptophyte plants, in contrast to pure steppes, the coenotic structure of which is formed predominantly by turf graminoids, with short and fibrous rhizal plants (Lavrenko 1940). The presence of graminoids is usually relatively low, with low coverage, but they are important as subdominant species in these communities. Calcareous petrophytic steppe communities are developed on short-profiled, shallow and skeletal soils (rendzic leptosols, gypsols) on carbonate sediments. Plants occupying such an environment have adapted to this rocky substrate by forming a strong, rod caudex type of root system to enhance growth. In terms of behavioral strategy, these plants are S-stress tolerators (Grime 1977). A characteristic feature of the flora of these communities is the presence of specific adaptive traits, because of which many, even dominant genera have vicarious races that are endemic to certain regions and indicate the identity and progressive nature of the development of these communities. Such living conditions and structural features of coenoses limit short-term fluctuation and mediumterm succession processes, and the defining process of coenoses development is microevolutionary changes that are manifested in species formation (Litvinov 1891).

Petrophytic steppes communities are unique: on the one hand they have high coenotic diversity, mosaic structure, floristic specificity and are characterized by extreme living conditions; and, on the other hand, they border communities with graminoids or mesophytic species dominance, which can spread to the petrophytic steppes' coenotic structure. Based on these criteria, the classification of these types of communities is extremely complicated, causing heated discussions among scientists for both dominant and floristic classification methods.

Lavrenko (1940), leader and undisputed expert on Eurasian steppes, considered petrophytic steppes to be vegetation with a dominance of xerophytic graminoids, but when chamaephytic species dominated in grasslands, he classified them as "thymiannyk" (derived from the genera name Thymus - the characteristic species).

Lavrenko (1973, 1980), Lavrenko et al. (1991) and Takhtandzhyan $(1937,1940)$ assumed these petrophytic steppes to be analogues of Mediterranean tomillars or as a part of Tragacantha grasslands phrygana with hemispheric cushion plants, and more widespread mountainxerophytic vegetation - phryganoids (Yaroshenko 1956, Gulisashvili et al. 1975, Kamelin 1979, Didukh 1981). However, Tragacantha and Thymus grasslands are distributed only in the steppe zone and are differentiated from
Mediterranean communities by their steppic characteristics (Tomollares substepposus) (Didukh 1992).

The ecological and floristical determination of these communities gives rise to some complex and debatable issues for several reasons. Firstly, diagnostic features such as boundaries between dominant species are blurred. Moreover, the rich floristic diversity, high level of endemism and the presence of specific calcephilous plants causes the occurrence of numerous syntaxa with a local distribution. The latter is further complicated by the fact that many endemic plants are ranked on a taxonomical level according to Ukrainian taxonomical literature (Klokov 1973, 1974, Mosyakin \& Fedoronchuk 1999), from subspecies to species, which then influences the vegetation classification.

Secondly, xerophytic conditions cause the penetration of pure steppe species that may be diagnostic in other steppe syntaxa. Moreover, diagnostic and characteristic species identified for rocky grasslands of Western Europe that have spread to more aridic and continental conditions, show different specificity in Ukraine. All this together complicates classification of these communities. Today, herbaceous vegetation occurring on calcareous substrata in Ukraine is represented mainly by the class Festuco-Brometea Br.-Bl. et Tx. ex Soo 1947; in particular by the order Stipo pulcherrimae-Festucetalia pallentis Pop 168, but communities occurring on developed sodcarbonate soils are also known and are classified within the orders Brachypodietalia pinnati Korneck 1974, Festucetalia valesiacae Soó 1947 and Tanaceto achilleifoliiStipetalia lessingianae Lysenko et Mucina 2016 (Mucina et al. 2016). In addition, cretophilous communities on chalk with poor floristic composition, and associated with the Central Russian Uplands, are described as a separate class, Helianthemo-Thymetea (Romashchenko et al. 1996, Didukh 1996, Didukh et al. 2018), and communities occurring in the highlands are treated as the class Elyno-Seslerietea Br.-Bl. 1948 (Mucina et al. 2016). Specific communities of spring ephemerals and succulents, in which a significant proportion of species are bryophytes, are also associated with calcareous bedrocks. They belong to the class Sedo-Scleranthetea Br.-Bl. 1955 (order Alysso-Sedetalia Moravec 1967). There are communities of the class Drypidetea spinosae Quezel 1964, order Onosmo polyphyllae-Ptilostemonetalia Korzhenevski 1990, in the Crimea Mountains. Such diversity of communities requires appropriate comparative analysis and evaluation of the classification of the order Stipo pulcherrimae-Festucetalia pallentis.

Communities of the order Stipo pulcherrimae-Festucetalia pallentis occur mainly on undeveloped soils formed on rock complexes of various geology, both sedimentary and crystalline. In particular, in Western and Central 
Europe, the alliance Alysso-Festucion pallentis Moravec in Holub et al. 1967, as well as Asplenio-Festucion pallentis Zólyomi 1936 corr. 1966, have been noted in the Eastern Alps and northern part of the Pannonian Basin, communities of which occur on silicate outcrops and Silurian limestones of Hercynian outcrops (Chytrý et al. 2007). The communities of Bromo pannonici-Festucion csikhegyensis first described by Zólyomi (1966) also occupy the northern fringes of the Pannonian Basin (Chytrý et al. 2007, Janišová et al. 2014, Mucina et al. 2016) and occur on calcareous substrata. On the other hand, communities of Chrysopogono-Festucion dalmaticae Borhidi 1996 occupy the southern fringes of the Pannonian Basin and occur on calcareous substrata. The alliances Saturejion montanae Horvat in Horvat et al. 1974 and PimpinelloThymion zygoidi Dihoru et Donita 1970, are endemic to Balkan countries (Aćić et al. 2015, Vassilev \& Apostolova 2013) and also occur on calcareous substrata. It should be added that dealpine relic communities described as the alliances Diantho lumnitzeri-Seslerion (Soó 1971) Chytrý et Mucina in Mucina et Kolbek 1993 and Seslerion rigidae Zólyomi 1936, mainly occur on calcareous substrata in Central Europe and the Eastern Carpathian Mountains (Janišová \& Dúbravková 2010, Dengler et al. 2012, Janišová et al. 2014).

This type of vegetation has thus been well described for Western and Central Europe but barely mentioned for Ukraine, only on class and order levels (Willner et al. 2017). Mucina et al. (2016) provided endemic alliances belonging to the order Stipo puclherrimae-Festucetalia pallentis as Potentillo arenariae-Linion czernjajevii described by Krasova \& Smetana (1999), occurring on Pontic limestone substrata in the southern Ukraine and Androsaco tauricae-Caricion humilis Didukh in Mucina et Didukh 2014, on Jurassic limestones in the Crimea Mountains. Mucina et al (2016) also noted that communities of the alliance Bromo pannonici-Festucion csikhegyensis occupy calcareous substrata of Ukrainian Podillia. Didukh \& Vasheniak (2018) discussed the presence of the alliance Bromo pannonici-Festucion csikhegyensis in Ukrainian Podillia and proposed an endemic alliance of the Podillia region as the alliance Galio campanulati-Poion versicoloris. Dubyna et al. (2019) confirmed the presence of the alliance Bromo pannonici-Festucion csikhegyensis and mentioned the association Poetum versicoloris within this alliance.

However, the existing fragmentary syntaxonomic classification does not reflect the diversity of petrophytic steppe vegetation on calcareous substrata, especially in Ukraine, since there is a significant variety characterized by different chemical compositions formed in different geological periods.
Taking into account the discussed syntaxonomy of calcareous petrophytic steppes of Ukraine and the rich diversity of calcareous bedrocks, we aimed to revise the vegetation data of Ukrainian petrophytic steppes with a comparison of available data from adjacent territories and to analyze the syntaxonomy and ecology at the alliance level.

\section{Study area}

The research was carried out on the territory of Ukraine and adjacent territories (Figure 1) on outcrops of calcareous bedrock. On the basis of the structure of the sediments, the vegetation of the Ukrainian part of the study region can be grouped into four types.

The first type represents outcrops of chalk scree slopes distributed in the following three regions: Volyn-Podillia (forest-steppe zone), Central Russian Upland (foreststeppe and steppe zones) and Crimean foothills. The vegetation is characterized by a lack of obligatory endemic calcephilous plants in calcephilous communities within the humid climates of forest-steppe and steppe zones with sufficient hydration of the chalk substrate, but a wide range of facultative calcephilous plants are present. These communities are rich in meadow-steppe elements tending toward carbonate substrata and are representives of the alliance Cirsio-Brachypodion. A significantly different situation is observed in communities in the arid conditions of the steppe zone, where communities contain many obligatory calcephilous plants and are characterized by high endemism. This is best seen in the chalk outcrops of the Central Russian Upland, where peculiar communities form. Famous geobotanists from the XIX-XX' turies designated such communities "hysopnik" (Litvinov 1891 ) and "low alpine communities" (Kozo-Poljanski 1911). According to Litvinov (1891), "hysopnik" included species of Cretaceous flora origin.

The second type of calcareous substrata is miocenic gypsum, which occurs only in Ukraine's Western Podillia (Opillia). These are solid sediments that appear on the surface in the form of cliffs, ridges and karst funnels. Even though they are in the humid climatic zone, the flora and plant communities are more specific and diverse here (Herenchuk 1979). The cliffs are characterized by communities with a dominance of succulents and terophytes (Alysso-Sedetalia), and chasmophytic (Asplenion rutae-murariae) and lichen communities (Verrucarietea nigriscentis).

The third type includes Tertiary Pontic and Sarmatian limestones that occur in Ukraine in various zones: forest (Mizockyi Ridge), forest-steppe and steppe zones. Limestone sediments with porous structures rise to the surface 


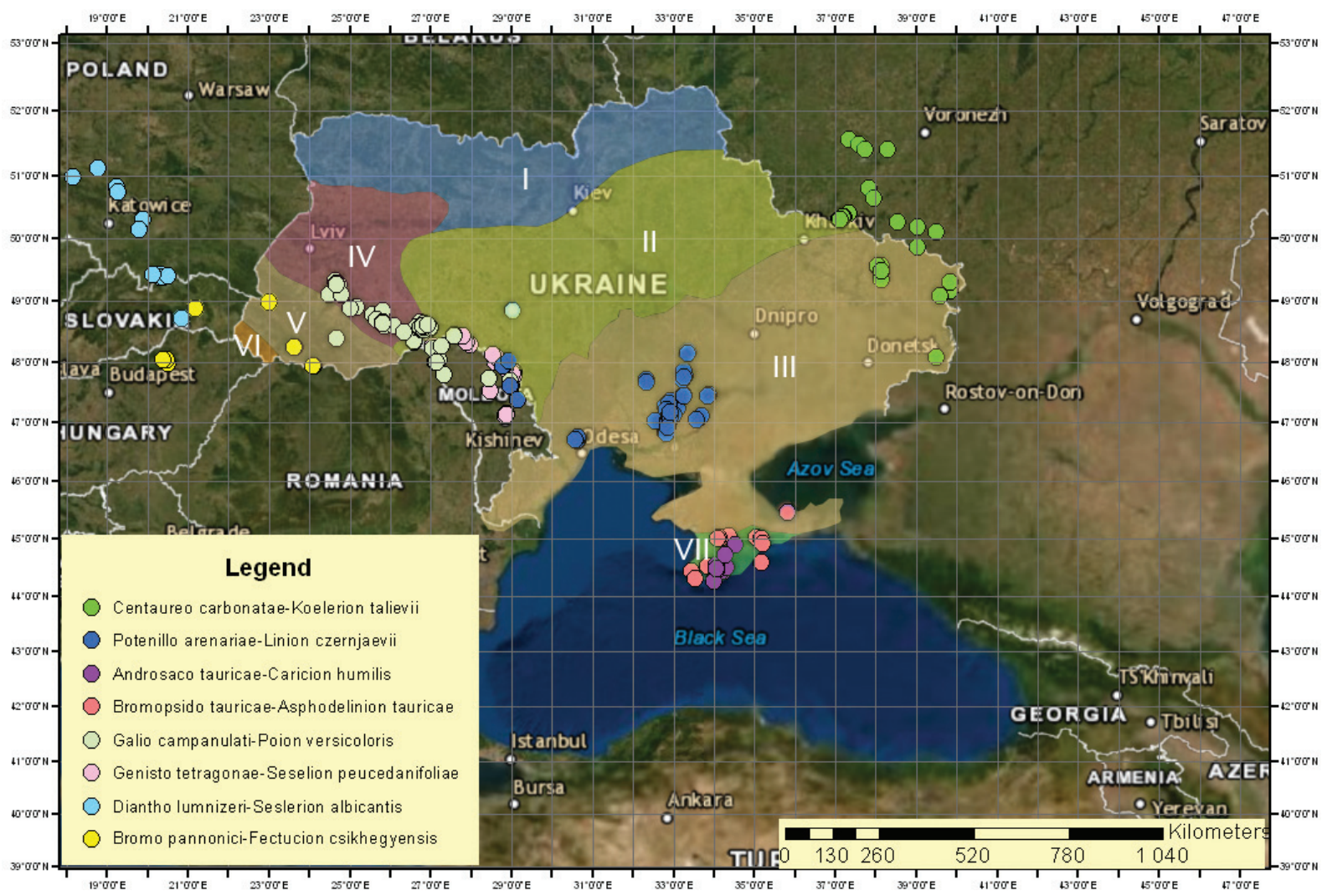

Figure 1: Study area of Ukraine and adjacent territories. The Ukrainian territory is presented by coloring of the geobotanical zoning, according to Didukh \& Shelyag-Sosonko (2003) as follows: I - Eastern European Province of pine-deciduous and deciduous forests; II - Eastern European Forest-Steppe Province of oak forests, steppe meadows and meadow steppes; III - Pontic Steppe Province; IV - Central European Forest-Steppe Province of deciduous forests; V - Carpathian-Alpine Mountain Province of forests and alpine vegetation; VI - Pannonian Forest-Steppe Province of heliophilic and nemoral forests, steppe meadows and meadow steppes; VII - Mediterranean Zone of deciduous forests, "pseudomaquis", "shyblyak" and "tomillars".

Slika 1: Preučevano območje Ukrajine in sosednjih območij. Teritorij je obarvan v skladu z geobotanično conacijo po Didukh \& Shelyag-Sosonko (2003): I - vzhodnoevropska provinca borovo-listopadnih in listopadnih gozdov; II - vzhodnoevropska gozdno-stepska provinca hrastovih gozdov, stepskih travišč in travnatih step; III - provinca pontske stepe; IV - srednjeevropska gozdno-stepska provinca listopadnih gozdov; V - karpatskoalpska gorska provinca gozdov in alpinske vegetacije; VI - panonska gozdno-stepska provinca svetloljubnih gozdov zmernega pasu, stepskih travišč in traviščnih step; VII - mediteranska cona listopadnih gozdov, "psevdomakija", "šibljak" in "tomilar".

in the form of several meter high vertical walls (Herenchuk 1980). The forest zone vegetation of this substrata type lacks specific communities, but further south there are typical Asplenion rutae-murariae and Alysso alyssoidisSedion alliances (Onyshchenko 2001), while in the arid steppe zone, communities with the presence of Parietaria judaica (Cymbalario-Parietariatea) grow in an environment with low precipitation conditions.

The fourth type relates to the Crimean Mountains, which are a northeastern massif of the folded-block system of the Mediterranean Geosynclinal Belt and consist of Upper Jurassic limestones and shales that emerge on the surface at varying heights of 3 to 1450 meters (RomanKish Mountain) a.s.l. (Didukh 1981). The diverse altitudinal conditions are reflected in the vegetation differentiations by the presence of separate vegetation types for each altitude zone. Petrophytic communities are specific in relation to other types of vegetation and are characterized by a number of species that grow on this extensive altitude range, as well as lichen communities (Verrucarietea nigrescentis, Protoblastenietea immersae and Collemateae cristati). However, height specificity is also observed (Didukh 1992, Khodosovtsev 2002). In contrast to the Western Carpathians, Ukrainian Carpathian limestone bedrocks occur in the Svydovets Massif and Marmarosh cliffs; in Transcarpathia only in the Velyka Uholka and Kuziy tracts (Herenchuk 1981). Such a diverse picture indicates a high variability of calcareous communities in Ukraine and requires more detailed comparative analysis. To understand the complete picture, we analyzed the available data from Ukraine, as well as from nearby territories with available databases of vegetation, in particu- 
lar from the Pannonian region (Slovak Karst Mountains, North Hungarian Mountains), where Mesozoic limestones, dolomites, sandstones and shales emerge and form rock complexes with the occurrence of the alliance Bromo pannonici-Festucion csikhegyensis (Dubravková \& Janišová 2010). The valleys of the river terraces of the Moravian Gate in southern Poland are composed of Miocene limestones and loesses, and the Kraków-Częstochowa Upland and Małoposlka Upland are composed of Jurassic chalk limestones (Kondracki 1965). The most similar to the Ukrainian geological structure is the Moldavian Plateau, Transnistria Upland, which is actually a continuation of the Volyn-Podillia Upland, composed of ancient sediments, and Sarmatian limestones, sandstones and Tortonian gypsum come to the surface (Pinzaru 1997).

\section{Materials and methods}

\section{Vegetation data collection}

We used our own phytosociological relevés, collected from Ukraine in 1975-2014 (plot size $10 \mathrm{~m}^{2}$ ) and in 2016-2019 (plot size $10 \mathrm{~m}^{2}$ ), and relevés obtained from adjacent territories extracted from the EVA database (Chytrý et al. 2016), including Poland, Hungary and the
Slovak Republic, and also from Moldova (Pinzaru 2006, 2015a, 2015b, 2015c) and Russia (Didukh et al. 2018) (Table 1), with assigned syntaxonomical status. The criterion for choosing data from adjacent territories was literature confirmation (Janišová et al. 2014, Mucina et al. 2016, Dubyna et al. 2019) of the presence of the same communities as in Ukraine.

\section{Vegetation data analysis}

The data were analysed in JUICE software (Tichý 2002). We used a TWINSPAN modified algorithm (Hill 1979): three pseudospecies cut level - 0, 5 and 25, Whittaker's method for distinguishing clusters. Diagnostic species for individual clusters were estimated based on the phi-coefficient (threshold of fidelity of more than 25\%), tested by Fisher's exact test $(\mathrm{p} \geq 0.01)$ (Chytrý et al. 2002), with all groups standardized to an equal size (Tichý \& Chytrý 2006). For the determination of highly constant species, we used a threshold of constancy of more than $50 \%$, and for constant species of more than $25 \%$. Identification at class and order levels was done using EVCL 2016 (Mucina et al. 2016) and EC-orders-v2-c (Willner et al. 2017) expert systems, respectively. The final cluster identification and affiliation at the alliance level was made based on

Table 1: Sources of vegetation data used. * An asterisk indicates approximate size of the plots.

Tabela 1: Uporabljeni viri vegetacijskih podatkov. ${ }^{*}$ Zvezdica predstavlja približno velikost popisnih ploskev.

\begin{tabular}{|c|c|c|c|}
\hline Source & $\begin{array}{c}\text { Region } \\
\text { Ukrain e } \\
\end{array}$ & $\begin{array}{l}\text { Number of } \\
\text { relevés }\end{array}$ & $\begin{array}{c}\text { Plot size } \\
\left(\mathrm{m}^{2}\right)\end{array}$ \\
\hline UDG (Kuzemko 2012) & $\begin{array}{c}\text { Ukraine: Dniester Canyon, Gologory-Krements Ridge, } \\
\text { Totry Ridge, Khotyn Upland }\end{array}$ & 247 & 10 \\
\hline Didukh et al. 2018 & Ukraine, Russia: Central Russian Upland & 233 & 10 \\
\hline Didukh Y.P. (unpublished relevés) & $\begin{array}{l}\text { Ukraine: Crimean Mountains, } \\
\text { Gologory-Kremenets Ridge }\end{array}$ & 81 & $100^{*}$ \\
\hline Didukh Y.P. (unpublished relevés) & Ukraine: Dnieper Upland, Black Sea Lowland & 60 & 10 \\
\hline Vasheniak I.A. (unpublished relevés) & $\begin{array}{c}\text { Ukraine: Svydovets Massif, Marmarosh Massif } \\
\text { (Marmarosh Cliffs), Dnieper Upland, Black Sea Lowland }\end{array}$ & 56 & 10 \\
\hline Dubyna et al. 2019 & Ukraine: Kuialnyk Estuary & 26 & 10 \\
\hline
\end{tabular}

Adjacent territories (nearby territories with available vegetation data)

Pinzaru 1997, Pinzaru 2006

Moldova: Moldavian Plateau, Transnistria Upland, Dniester River valley

EVA (Chytrý et al. 2016), Polish Database (Kącki \& Śliwiński 2012)

EVA (Chytrý et al. 2016)

EVA (Chytrý et al. 2016)
Poland: Małoposlka Upland, Kraków-Częstochowa Upland, Moravian Gate)

Hungary: North Hungarian Mountains

Slovak Republic: Slovak Karst Mountains Ukraine: Skolivski Beskydy 
literature sources (Kukovytsia et al. 1994, Pinzaru 1997, Mucina et al. 2016). Additionally, we used the Slovak expert system (Janišová et al. 2007) for identification of some clusters at the alliance level with questionable syntaxonomy.

The vascular plant species nomenclature is according the Euro+Med Database checklist (http://www.emplantbase.org). If species were interpreted as synonyms or subspecies according to the Euro+Med Database checklist, we combined them as species aggregates (Appendix 1).

At the first stage of data preparation, the complete array of data from 989 relevés was interpreted subjectively as petrophytic calcareous steppes, according to their floristic composition and substantiated by the EVCL2016 expert system (Mucina et al. 2016). The following relevés were omitted: Sedo-Scleranthetea (9 relevés), CarpinoFagetea sylvaticae (3 relevés), Trifolio-Geranietea (11 relevés), Asplenietea trichomanis (1 relevé), Elyno-Seslerietea (1 relevé), Artemisietea vulgaris (6 relevés), Drypidetea spinosae (2 relevés), with additional unclassified records (65 relevés). The expert system confirmed data for 891 relevés of the class Festuco-Brometea. In the second stage of data preparation, we used the EC-orders-v2-c expert system for additional processing (Willner et al. 2017) and the resulting data was interpreted as the orders Festucetalia valesiacae, Stipo pulcherrimae-Festucetalia pallentis and Brachypodietalia pinnati. We rejected mesophytic communities of the order Brachypodietalia pinnati $(265$ relevés) and cretophilous communities of the class $\mathrm{He}^{-}$ lianthemo-Thymetea, which were not recognized by the expert system but are recognizable by diagnostic species (138 relevés). Xerophytic communities occurring on calcareous substrata of the orders Stipo pulcherrimae-Festucetalia pallentis and Festucetalia valesiacae were retained based on the expert system results. The final dataset of 488 relevés was further processed using the TWINSPAN algorithm.

Syntaxa nomenclature followed Kukovytsia et al. (1994), Pinzaru (1997) and Mucina et al. (2016). The new syntaxon is described according the rules of the "International Code of Phytosociological Nomenclature" (Theurillat et al. 2020).

DCA (Detrended Correspondence Analysis) was conducted in order to assess the impact of environmental factors on plant communities. Phytoindication scales of Y. Didukh (Didukh 2011) are comparable to other environmental indicator values (Ellenberg) and reflect amplitude indices of the species characterized by the following dimensions: soil humidity ( $\mathrm{Hd}-23$ grades), variability of damping ( $\mathrm{fH}-11$ grades), soil acidity ( $\mathrm{Rc}-15$ grades), total salt regime ( $\mathrm{Sl}-19$ grades), carbonate content $(\mathrm{Ca}-13$ grades $)$, nitrogen content $(\mathrm{Nt}-11$ grades $)$, aeration of the soil (Ae - 15 grades), thermoregime of the climate ( $\mathrm{Tm}-17$ grades), humidity of the climate $(\mathrm{Om}-23$ grades), continentality of the climate $(\mathrm{Kn}-17$ grades), cryoregime of the climate $(\mathrm{Cr}-15$ grades) and lightness in the community ( $\mathrm{Lc}-9$ grades). Phytoindication values were passively projected onto a DCA graph. We used R programme (R Core Team 2013) to visualize the DCA.

Additionally, environmental parameter differences between alliances were estimated with one-way ANOVA in the STATISTICA 10.0 program (StatSoft 2010). Tukey's HSD post hoc test at $\alpha<0.05$ was used to identify significant differences among groups. "Box-and-whiskers" plots of the environmental characteristics of the alliances were drawn and the results of the post hoc Tukey's test were visualized as letters for homogeneous groups.

\section{Results}

We obtained a dendrogram of 5 clusters (Figure 2) of groups of relevés based on floristic similarity and their geographical position, defined as follows: A (61 relevés) from Central Europe and Ukrainian Transcarpathia; B (218 relevés), mainly from the Volyn-Podillia Upland, Dniester Valley and its tributaries, and the Transnistria Upland; C (62 relevés) from the Crimean Mountains; D (124 relevés) from the Dnieper Upland and Black Sea Lowland; E (144 relevés) communities from the Central Russian Upland. Clusters A and B include communities of the humid north-western regions of Ukraine, while $\mathrm{C}, \mathrm{D}$ and $\mathrm{E}$ are communities of the arid, south-eastern regions of Ukraine. We did not exclude Festucetalia valesiacae relevés because in each group there was also a certain proportion of Stipo pulcherrimae-Festucetalia pallentis relevés and we assumed that Willner et al. (2017) did not include data from the Eastern Ukraine in the meta-analysis and these communities could also belong to the order Stipo pulcherrimae-Festucetalia pallentis.

The further processing of each group separately resulted in eight clusters, presented in a synoptic table (Table 2). The first cluster (group A) includes calcareous petrophytic communities from Central Europe (Hungary, Slovak Republic, Ukrainian Transcarpathia). Based on analysis of the floristic composition, we identified it as Bromo pannonici-Festucion csikhegyensis. The second cluster was selected from within the same group (A); it includes only relevés from the Małopolska Upland, Kraków-Częstochowa Upland and Moravian Gate, was interpreted as the alliance Diantho lumnitzeri-Seslerion albicantis and there is no evidence of the presence of these communities in Ukraine (Figure 1). The third cluster was 


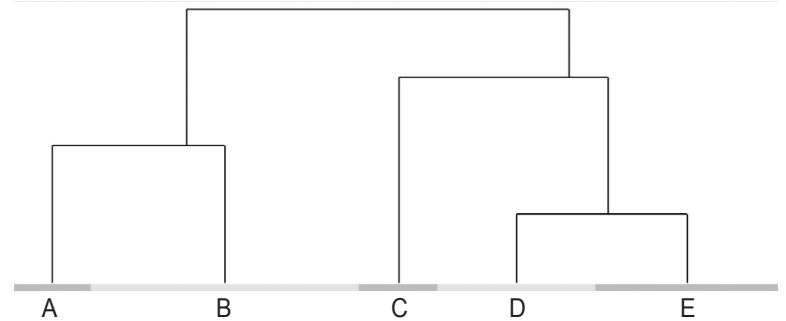

Figure 2: Results of TWINSPAN algorithm evaluation. A - relevés from Central Europe and Transcarpathia; B - relevés mainly from Volyn-Podillia, Transnistria Uplands and Dniester Canyon; $\mathrm{C}$ - relevés from the Crimean Mountains; D - relevés from the Dnieper Upland and Black Sea Lowland; E - releves from the Central Russian Upland.

Slika 2: Rezultati z TWINSPAN algoritmom.

A - popisi iz srednje Evrope in Transkarpatov; B - popisi predvsem z območja Volyn-Podillia, višavja Transnistria in kanjona reke Dniester; $\mathrm{C}$ - popisi s Krimskega gorovja; D - popisi z višavja Dnieper in črnomorske nižine; E - popisi s Srednjeruskega višavja.

extracted from group B and consists of communities occurring on Neogene limestones, gypsum and sandstones of the Volyn-Podillia and Transnistria Uplands; it was classified as the alliance Genisto tetragonae-Seselion peucedanifoliae. The fourth cluster was also taken from group $\mathrm{B}$ and is represented by communities of steep slopes the walls of Dniester Canyon, where the climatic effect of "warm Podillia" is observed (Herenchuk 1980); it was interpreted as the alliance Galio campanulati-Poion versicoloris. Group C, which combines communities from the Crimean Mountains, was also divided into two clusters: the fifth cluster includes vegetation developed from the lowlands to $900 \mathrm{~m}$ a.s.l., classified in a new alliance - Bromopsido tauricae-Asphodelinion tauricae, while the sixth cluster represents vegetation from the alpine zone, of the alliance Androsaco tauricae-Caricion humilis. The seventh cluster, allocated within group D, includes communities of the southern forest-steppe zone of the Dnieper Upland and Black Sea Lowland, which are assigned to the alliance Potentillo arenariae-Linion czernjajevii. The eighth cluster consists of communities of the alliance Centaureo carbonatae-Koelerion talievii.

The syntaxonomic diversity of the order can be shown in the following scheme:

Class Festuco-Brometea Br.-Bl. et Tx. ex Soó 1947

Order Stipo pulcherrimae-Festucetalia pallentis Pop 1968

1. Bromo pannonici-Fectucion csikhegyensis Zólyomi 1966 corr. Mucina in Di Pietro et al. 2015

2. Diantho lumnitzeri-Seslerion albicantis (Soó 1971) Chytrý et Mucina in Mucina et Kolbek 1993 (not confirmed in Ukraine)

3* Genisto tetragonae-Seselion peucedanifoliae Pinzaru 1997
$4^{*}$ Galio campanulati-Poion versicoloris Kukovitsa et al. 1994

5. Bromopsido tauricae-Asphodelinion tauricae all. nova

6. Androsaco tauricae-Caricion humilis Didukh in Didukh et Mucina 2014

7. Potentillo arenariae-Linion czernjajevii Krasova et Smetana 1999

$8^{*}$ Centaureo carbonatae-Koelerion talievii Romashchenko et al. 1996

* An asterisk indicates a provisional decision on the syntaxonomical status of the alliance

Some examples of communities of distinctive vegetation types are presented on Figure 3.

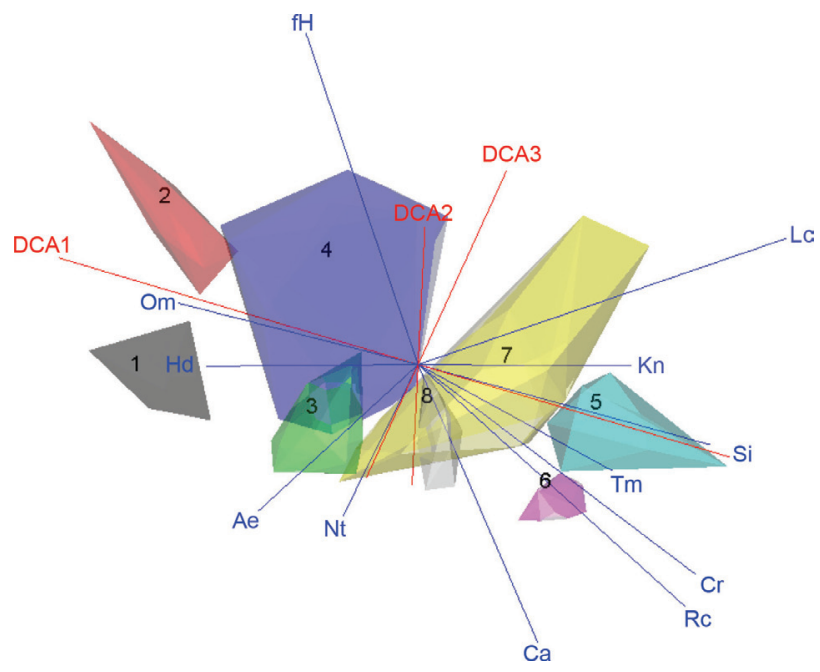

Figure 3: Ecological differences among the eight syntaxa

1 - Bromo pannonici-Fectucion csikhegyensis, 2 - Diantho lumnitzeri-

Seslerion albicantis, 3 - Genisto tetragonae-Seselion peucedanifoliae,

4 - Galio campanulati-Poion versicoloris, 5 - Bromopsido tauricae-

Asphodelinion tauricae, 6-Androsaco tauricae-Caricion humilis,

7 - Potentillo arenariae-Linion czernjaevii, 8 - Centaureo carbonataeKoelerion talievii.

a) $\mathrm{Hd}$ - soil humidity, b) $\mathrm{fH}$ - variability of damping, c) $\mathrm{Rc}-$ soil acidity, d) $\mathrm{Sl}$ - total salt content in soil, e) $\mathrm{Ca}$ - calcium/magnesium content in soil, f) $\mathrm{Nt}$ - nitrogen content in soil, g) Ae - soil aeration, h) $\mathrm{Tm}$ - thermal climate, i) Om - ombroregime, j) Kn - continental climate, k) $\mathrm{Cr}$ - cryoclimate, 1) Lc - light in the community.

Slika 3: Ekološke razlike med osmimi sintaksoni

1 - Bromo pannonici-Fectucion csikhegyensis, 2 - Diantho lumnitzeriSeslerion albicantis, 3 - Genisto tetragonae-Seselion peucedanifoliae,

4 - Galio campanulati-Poion versicoloris, 5 - Bromopsido tauricaeAsphodelinion tauricae, 6-Androsaco tauricae-Caricion humilis,

7 - Potentillo arenariae-Linion czernjaevii, 8 - Centaureo carbonataeKoelerion talievii.

a) Hd - vlažnost tal, b) fH - variabilnost vlažnosti, c) Rc - kislost tal, d) Sl - skupna vsebnost soli v tleh, e) Ca - vsebnost kalcija/magnezija v tleh, f) Nt - vsebnost dušika v tleh, g) Ae - zračnost tal, h) $\mathrm{Tm}$ - toplota, i) $\mathrm{Om}$ - ombrorežim (padavine), j) Kn - kontinentalnost, k) Cr - krioklima, l) Lc - svetloba v združbi. 

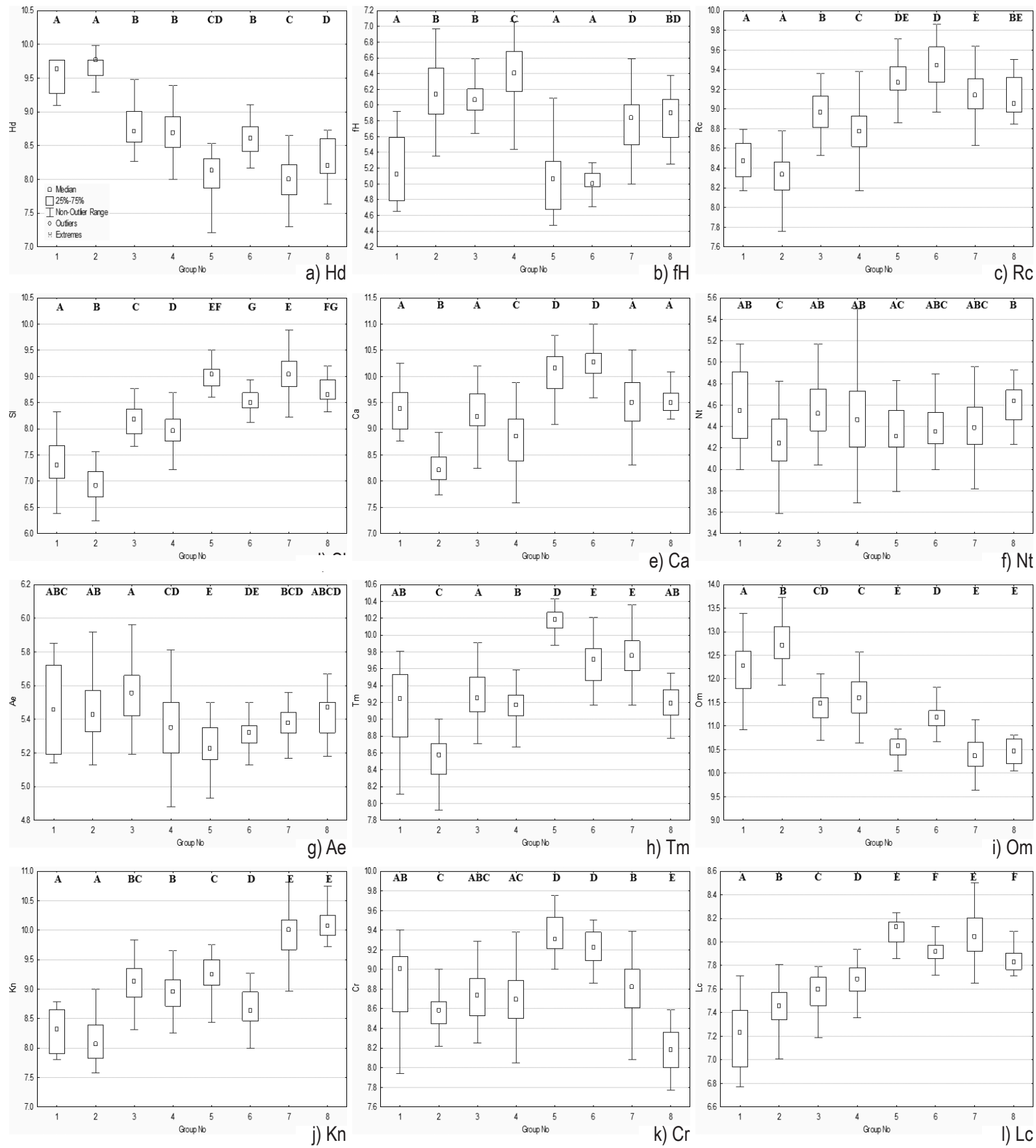

Figure 4: Detrended Correspondence Analysis of the distinguished syntaxa. 1 - Bromo pannonici-Fectucion csikhegyensis, 2 - Diantho lumnitzeriSeslerion albicantis, 3 - Genisto tetragonae-Seselion peucedanifoliae, 4 - Galio campanulati-Poion versicoloris, 5 - Bromopsido tauricae-Asphodelinion tauricae, 6 -Androsaco tauricae-Caricion humilis, 7 - Potentillo arenariae-Linion czernjaevii, 8 - Centaureo carbonatae-Koelerion talievii Acronyms: $\mathrm{Hd}$ - soil humidity, $\mathrm{fH}$ - variability of damping, $\mathrm{Rc}$ - soil acidity, $\mathrm{Sl}$ - total salt content in soil, $\mathrm{Ca}$ - calcium/magnesium content in soil, $\mathrm{Nt}$ - nitrogen content in soil, Ae - soil aeration, $\mathrm{Tm}$ - thermal climate, $\mathrm{Om}$ - ombroregime, $\mathrm{Kn}$ - continental climate, $\mathrm{Cr}$ - cryoclimate, Lc - light in the community.

Slika4: Korespondenčna analiza z odstranjenim trendom različnih sintaksonov. 1 - Bromo pannonici-Fectucion csikhegyensis, 2 - Diantho lumnitzeriSeslerion albicantis, 3 - Genisto tetragonae-Seselion peucedanifoliae, 4 - Galio campanulati-Poion versicoloris, 5 - Bromopsido tauricae-Asphodelinion tauricae, 6 - Androsaco tauricae-Caricion humilis, 7 - Potentillo arenariae-Linion czernjaevii, 8 - Centaureo carbonatae-Koelerion talievii Okrajšave: a) Hd - vlažnost tal, b) fH - variabilnost vlažnosti, c) Rc - kislost tal, d) Sl - skupna vsebnost soli v tleh, e) Ca - vsebnost kalcija/ magnezija v tleh, f) $\mathrm{Nt}$ - vsebnost dušika v tleh, g) Ae - zračnost tal, h) Tm - toplota, i) Om - ombrorežim (padavine), j) Kn - kontinentalnost, k) $\mathrm{Cr}$ - krioklima, l) Lc - svetloba v združbi. 


\section{Environmental characteristics of calcareous petrophytic steppes}

The DCA (Figure 4) results show that the main factors affecting the vegetation diversity of studied petrophythic steppes are related to DCA1, acidity $(\mathrm{Rc})$, cryoregime $(\mathrm{Cr})$ and light in communities (Lc), the closest to DCA2 is nitrogen content $(\mathrm{Nt})$, and to DCA3 are ombroregime $(\mathrm{Om})$ and aeration $(\mathrm{Ae})$. Other environmental factors play a smaller role in differentiation of the syntaxa. The right side of the ordination diagram contains alliances of arid communities: Bromopsido tauricae-Asphodelinion tauricae, Androsaco tauricae-Caricion humilis, Potentillo arenariae-Linion czernjaevii, Centaureo carbonatae-Koelerion talievii from the steppe zone of Ukraine. The left side contains alliances of Central Europe and partly Eastern Europe: Bromo pannonici-Fectucion csikhegyensis, Diantho lumnitzeri-Seslerion albicantis, Genisto tetragonae-Seselion peucedanifoliae, Galio campanulati-Poion versicoloris occurring mainly in the forest-steppe zone of Ukraine. The alliances Potentillo arenariae-Linion czernjaevii and Centaureo carbonatae-Koelerion talievii occupy a central position on the ordination diagram and this indicates that these alliances may be ecologically and floristically similar.

Detailed analysis of variance verified that all alliances have a minimum differentiation across one or more factors. This demonstrates the specificity of the ecospace (econiche) of these types of vegetation (Figure 5). According to environmental indices, the first group of four alliances of the north-humid zone are significantly differentiated from the south-arid zone alliances. The amplitude of soil moisture indicator $(\mathrm{Hd})$ values varies from 7.8 to 9.8 , whereby soils are moistened with slight or moderate wetting by precipitation of the root-containing layer, which in terms of the structure of carbonates, determines the moisture deficit. The highest humidity indices are for communities of the western regions of the Carpathians and differ from the latter, while the lowest values of this index, i.e., more xerophytic conditions, are observed for the alliances Bromopsido tauricae-Asphodelinion tauricae and Potentillo arenariae-Linion czernjajevii. With the exception of the first and second, the third and fourth, as well as the third and sixth, all alliances are well differentiated, since the p-values for these communities are much less than the allowable value ( $p$-value $\leq 0.05$ ) The fifth and seventh alliances are identical for these environmental factors ( $p$-value $=0.99)$.

The amplitude of variability of damping ( $\mathrm{fH}$ ) ranges from 4.6 to 6.6 points for soil with irregular moisture, when only the top layer is wet (Didukh 2012). The communities of the first, fifth and sixth alliances have relatively more stable humidification, while the largest fluctuations are characteristic of the fourth alliance.
The level of acidity (Rc) fluctuates slightly (8.2-9.6 points, from neutrophilic to basophilic). Across acidity vectors, except for the first two alliances, there is no differentiation among the alliances; for example, for the first and second $(\mathrm{p}$-value $=0.78)$, fifth and sixth $(\mathrm{p}$-value $=$ $0.51)$, and fifth and seventh alliances ( $\mathrm{p}$-value $=0.10)$ (Appendix 2). The indicators of salinity (Sl), on the other hand, have a much wider amplitude (6.6-9.3 points), ranging from soils enriched with bicarbonate salts to the absence of signs of salinity. Extreme positions are occupied by the Central European alliances and the alliances of the Northern Black Sea Coast. Most alliances are well differentiated, although the sixth and eighth $(\mathrm{p}$-value $=$ $0.43)$ and the fifth and seventh ( $\mathrm{p}$-value $=0.99)$, do not show visible differentiation. In terms of the carbonate content, the amplitude fluctuates from 8.0 to 10.4 points (soils enriched with calcium ions), whereby the wettest substrata of the second alliance have the least impact of carbonates on flora (Table 1). Communities of the second alliance are rich in species that are indifferent to substrata. The Crimean substrata (fifth and sixth alliances), enriched with endemic obligatory calcephilous plants, have the greatest impact on flora. The most similar are the first and third ( $\mathrm{p}$-value $=0.99)$, third and seventh $(\mathrm{p}$-value $=$ $0.88)$, fifth and sixth ( $\mathrm{p}$-value $=0.96$ ) and seventh and eighth ( $\mathrm{p}$-value $=0.99)$ alliances. In terms of nitrogen content $(\mathrm{Nt})$ and aeration $(\mathrm{Ae})$, there is no observed differentiation among the determined alliances, with their indices fluctuating within the 0.6-0.7 range (well aerated soils poor in mineral contents).

Differentiation is more pronounced according to climatic indicators. The thermoregime index values fluctuate between 8.8 and $10.3\left(1842-2156 \mathrm{MJ}^{*} \mathrm{~m}^{2 *}\right.$ year), which corresponds to the zonal indicators of the southern forest-steppe and steppe zones). The lowest values are characteristic of the western dry grasslands of Poland, while the highest values were detected for communities of the southern lowlands of Crimea. The first and eighth $(p$-value $=1.0)$, first and third ( $p$-value $=0.69)$ and sixth and seventh ( $p$-value $=0.45)$ alliances have the highest degree of similarity. The amplitude breadth of the cryoregime indices has a range of 8.0-9.5 and is characterized by a January mid- temperature of $-2--6^{\circ} \mathrm{C}$. The coldest conditions are characteristic of the petrophytic steppes of the Central Russian Upland, where snow cover is blown by steppe winds, and the warmest conditions are characteristic of Crimean communities, for which the mean January temperature isotherm delineates positive values. The most similar are the first and third ( $\mathrm{p}$-value $=0.81$ ), first and seventh $(p$-value $=0.99)$ and third and fourth $(p$-value $=1.0)$ alliances. The breadth of amplitude of the continentality index $(\mathrm{Kn})$ is wider $(7.8-10.2)$, the hemicontinental 

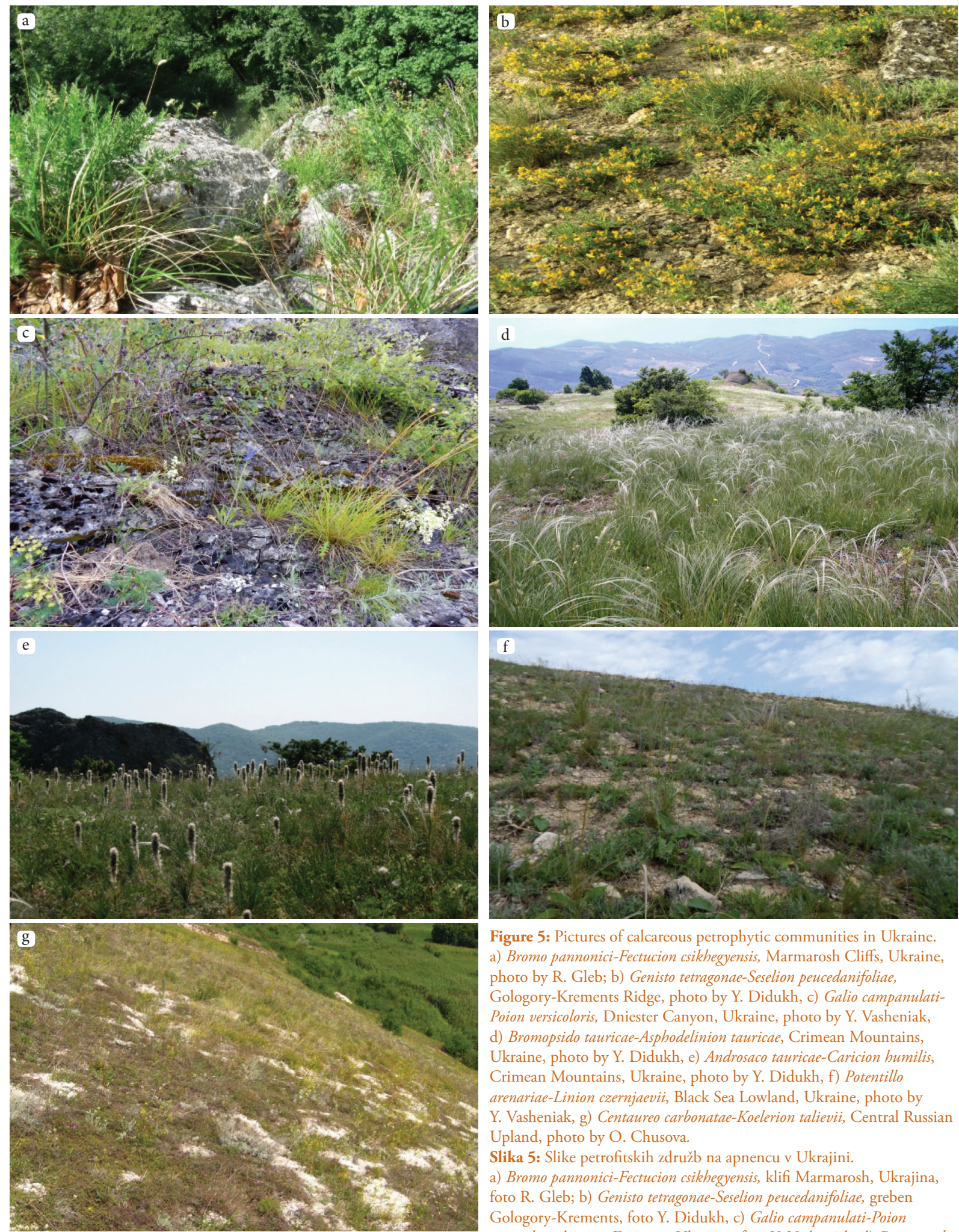

Figure 5: Pictures of calcareous petrophytic communities in Ukraine. a) Bromo pannonici-Fectucion csikhegyensis, Marmarosh Cliffs, Ukraine, photo by R. Gleb; b) Genisto tetragonae-Seselion peucedanifoliae, Gologory-Krements Ridge, photo by Y. Didukh, c) Galio campanulatiPoion versicoloris, Dniester Canyon, Ukraine, photo by Y. Vasheniak, d) Bromopsido tauricae-Asphodelinion tauricae, Crimean Mountains, Ukraine, photo by Y. Didukh, e) Androsaco tauricae-Caricion humilis, Crimean Mountains, Ukraine, photo by Y. Didukh, f) Potentillo arenariae-Linion czernjaevii, Black Sea Lowland, Ukraine, photo by Y. Vasheniak, g) Centaureo carbonatae-Koelerion talievii, Central Russian Upland, photo by O. Chusova.

Slika 5: Slike petrofitskih združb na apnencu v Ukrajini.

a) Bromo pannonici-Fectucion csikhegyensis, klifi Marmarosh, Ukrajina, foto R. Gleb; b) Genisto tetragonae-Seselion peucedanifoliae, greben Gologory-Krements, foto Y. Didukh, c) Galio campanulati-Poion versicoloris, kanjon Dniester, Ukrajina, foto Y. Vasheniak, d) Bromopsido tauricae-Asphodelinion tauricae, Krimsko gorovje, Ukrajina, foto Y. Didukh, e) Androsaco tauricae-Caricion humilis, Krimsko gorovje, Ukrajina, foto Y. Didukh, f) Potentillo arenariae-Linion czernjaevii, črnomorska nižina, Ukrajina, foto Y. Vasheniak, g) Centaureo carbonatae-Koelerion talievii, Srednjerusko višavje, foto O. Chusova. 
conditions according to the Ivanov continentality value (1959) are $123-147 \%$ and correlate with the isochores of Ukraine. Carpathian and Małopolska Upland communities have the lowest values of continentality and the petrophytic steppes of the Black Sea Coast and Middle Russian Upland have the highest indices. The most similar are the first and second ( $\mathrm{p}$-value $=0.98)$, third and fourth $(p$-value $=0.14)$ and seventh and eighth $(p$-value $=0.57)$ alliances. The ombroregime amplitude, which depends on the amount of evaporation of precipitation and reflects the hydrothermal regime, fluctuates from 10.2 to 12.5 (13.1), whereby the amount of evaporating precipitation is higher than the amount of precipitation $(0-600 \mathrm{~mm})$ (Ivanov 1957). Accordingly, the lowest precipitation deficit is characteristic of the Carpathian alliances, on which $1500 \mathrm{~mm}$ falls annually, and the highest is the petrophytic steppes of the Black Sea Coast and Middle Russian Upland, where $400 \mathrm{~mm}$ falls but, with the average annual temperature and the porosity of their chalk substrates, there is a sharp deficit of precipitation. According to light indices (Lc), all petrophytic steppes have high values of heliophytes, the highest level being characteristic of the petrophytic steppes of Crimea and the Black Sea Coast, while the lowest is for Carpathian communities because of the presence of shrubs (Cotinus coggygria, Cotoneaster integerrimus agg., Spiraea media, Sorbus aria). Significant differentiation among all alliances can be observed, except the fifth and seventh, and sixth and eighth alliances.

\section{Discussion}

Based on comparative analysis and ecological assessment, we classified communities formed on carbonate dense (not mobile) substrata, with low-capacity soils or the absence thereof, to the order Stipo pulcherrimae-Festucetalia pallentis. The herb layer (hemicryptophyte and chamaephyte plants) varies considerably (from 20 to $80 \%$ ). With increasing soil depth in dry conditions, these plants are replaced by communities of Festucetalia valesiacae (Festucion valesiacae, Stipion lessingianae) and, in wetter conditions, with a predominance of xeromesophytes and mesoxerophytes - communities of Brachypodietalia pinnati. Communities with a higher share of therophytes, and lichen communities in the absence of soil, belong to the class Sedo-Scleranthetea (Alysso alyssoides-Sedion). The communities of chamaephytes of the Central Russian Upland on mobile chalk substrata belong to Thymo cretacei-Hyssopetalia cretacei and, on the southern coast of Crimea, to Drypidetea.

The specificity of communities of the order Stipo pulcherrimae-Festucetalia pallentis is due to soil deficiency, so the possibility of serial and fluctuational changes is very limited in Ukraine. Carbonates, which are sedimentary rocks of extinct organisms, are a substrate of active morphogeny and speciation, as evidenced by the high endemism of the flora and variability of morphological features, especially in xerophytic conditions. Their development and dynamics are thus accompanied by phylogenetic processes that we interpret as synevolutionary (Didukh 2019). Willner (2020) suggests considering the alliance to be the result of synevolution of characteristic species that have a high constancy in the communities.

The alliance Bromo pannonici-Festucion csikhegyensis has been reported for Ukraine (Mucina et al. 2016, Dubyna et al. 2019) and is represented by a single association, Poetum versicoloris. It should be emphasized that Poetum versicoloris was first described from the Dniester Valley within the alliance Galio campanulati-Poion versicoloris of the order Stipo pulcherrimae-Festucetalia pallentis (Kukovytsia et al. 1994), but was then transferred to the alliance Artemisio marschalliani-Elytrigion intermediae of the order Festucetalia valesiacae (Korotchenko 2004) and there is a questionable presence of the alliance Bromo pannonici-Festucion csikhegyensis in the Dniester Valley (Didukh \& Vasheniak 2018). It should be noted that diagnostic species of Bromo pannonici-Festucion csikhegyensis (Dorycnium pentaphyllum, Fumana procumbens, Jovibarba globifera, Poa badensis) do not occur in the Volyn-Podillia Upland, but only in Central Europe and Pannonia (Janišová \& Dúbravková 2010, Hegedüšová et al. 2014, Chytrý et al. 2017). The Pannonian Province, in terms of geobotanical zoning of Ukraine (Figure 1) reaches only to Transcarpathia, so it is quite logical that relevés made on the Marmarosh cliffs at altitudes from $427 \mathrm{~m}$ to $998 \mathrm{~m}$, on limestone slopes of different steepness $\left(15-70^{\circ}\right)$, grouped into the cluster recognized by the Slovak expert system (Janišová et al. 2007) as the alliance Bromo pannoniciFestucion csikhegyensis (78\% relevés). These communities have been recognized as the association Seslerietum heuflerianae (Table 1) with a herb layer cover of 50-60\%, rich in hemicryptophyte (Carex humilis, Saxifraga paniculata, Sesleria heuflerana) and low growing phanerophyte plants (Cotoneaster integerrimus agg., Sorbus aria, Spiraea media). They are currently at a stage of succession and have been transferred to the alliance Diantho lumnitzeriSeslerion albicantis (Janišová \& Dúbravková 2010), but the syntaxonomical affiliation of these communities must be checked by supra-regional analysis, including the data from Ukraine.

Additionally, we have added the data designated "Bromo pannonici-Festucion csikhegyensis alliance" extracted from the Polish database to check our hypothesis about the presence of this alliance in the remaining parts of 
Ukraine, especially in the Volyn-Podillia Upland. As a result, these relevés were combined within the second cluster and recognized by the Slovak expert system (Janišová et al. 2007) as the alliance Diantho lumnizeri-Seslerion albicantis ( $53 \%$ relevés). It should be noted that the presence of this alliance on the territory of Poland was confirmed by Kącki et al. (2013), although none of the relevés from the Volyn-Podillia Upland were included in the cluster with Polish relevés.

The alliance Genisto tetragonae-Seselion peucedanifoliae (Pinzaru 1997) is similar in floristic composition and ecological conditions to the alliance Galio campanulatiPoion versicoloris, and further doubts are raised about its syntaxonomic affiliation: it was originally assigned to Stipo pulcherrimae-Festucetalia pallentis (Pinzaru 1997), and later to the order Helinthemo-Thymetalia cretacei (Rushchuk et al. 2005), which, in our opinion, is unjustified, since many diagnostic cretophilous species for this order (Artemisia hololeuca, A. salsoloides, Euphorbia petrophila, Hyssopus cretaceous, Matthiola fragrans, Thymus calcareus) are absent, although communities are dominated by chasmophyte plants (Thymus sp.), rather than hemicryptophytes. We observed such communities on Neogene outcrops of the Volyn-Podillia Upland and Transnistria Upland, particularly on Sarmatian limestones, sandstones, Tortonian gypsum, on slopes of different aspect $(\mathrm{N}, \mathrm{NW})$ and steepness $\left(10-65^{\circ}\right)$ and some of them are similar to Brachypodietalia pinnati communities in floristic composition, since they often occupy adjacent areas. The cover of such communities can reach $80 \%$, often dominated by hemicryptophytes (Aster amellus, Astragalus pseudoglaucus, Carex humilis, Helictotrichon desertorum, Inula ensifolia).

Didukh \& Vasheniak (2018) consider communities of the alliance Galio campanulati-Poion versicoloris to occur on outcrops of Neogene limestones and sandstones, but these communities occur mainly on well-eroded slopes, where more ancient Paleozoic and Mesozoic rocks (sandstones, marls, chalk, siltstones, shales, limestones) crop out, and are formed on washed-off leptosols, of various aspect and steepness $\left(1-70^{\circ}\right)$. The cover in such communities can reach $60 \%$, and Allium podolicum, Carex humilis, Poa versicolor, Seseli hippomarathrum and Stipa pulcherrima dominate. They are mainly distributed in the valley of the Dniester River and its tributaries, and are mostly formed in canyon-like landscapes on the middle and lower terraces of canyons, consisting of walls and shelves.

Given that communities of the alliances Genisto tetragonae-Seselion peucedanifoliae and Galio campanulati-Poion versicoloris occur mainly in the Eastern European (Sarmatian) forest-steppe and partly Pontic steppe provinces
(Figure 1), most species from Pannonia gradually disappear from west to east and the proportion of Pontic and endemic species increases (Zaverucha 1985). The results of the Slovak expert system (Janišová et al. 2007) evaluation showed that Bromo pannonici-Festucion csikhegyensis communities compose only $26 \%$ of relevés. It has to be added that, according to the theory of Willner (2020, neoendemic species of the Volyn-Podillia and Transnistria Uplands (Krytsjka 2010), which are connected to the Eastern European Pleistocene steppes (Astragalus pseudoglaucus, Seseli rigidum subsp. peucedanifolium), can be considered to be characteristic species of the alliance Genisto tetragonae-Seselion peucedanifoliae. On the other hand, neoendemic species with Eastern-European and sub-Mediterranean genesis connections (Allium podolicum, Poa versicolor), which frequently occur (Table 1) in the Dniester Valley, can be considered to be characteristic species of the alliance Galio campanulati-Poion versicoloris. In view of these arguments, we provisionarily propose considering these alliances to be eastern vicariants of the alliance Bromo pannonici-Festucion csikhegyensis but the final syntaxonomical decision should be accepted on the basis of supra-regional analysis.

The alliance Androsaco tauricae-Caricion humilis was considered by Didukh (1981) to be within the order Festucetalia valesiacae, but it was later transferred to Bromopsidetalia cappadocicae Didukh in Saitov et Mirkin 1991, which was not validly described (Korzhenevskii 1990, Saitov \& Mirkin 1991), and was later included in Stipo pulcherrimae-Festucetalia pallentis (Didukh \& Mucina 2014, Mucina et al. 2016). These are communities of petrophytic meadow steppes of table-like peaks of the Crimean Mountains (called "Yaila"), which are distributed at an altitude of $900-1450 \mathrm{~m}$ a.s.l. with a moderately cool climate $\left(+5.7^{\circ} \mathrm{C}\right)$, with an average temperature in January of $-3.9^{\circ} \mathrm{C}$ and in July of $+15.4^{\circ} \mathrm{C}$, and an average annual precipitation of 650-1050 mm (Ved 2000). They develop on outcrops of dense or crushed Upper Jurassic limestones on gentler slopes (up to $300 \mathrm{~m}$ ) and on convex peaks with smooth or differentiated microreliefs, whereby low-strength, sod-carbonate rendzina, or washed-off soils accumulate. Herb layer coverage is from 30 to $80 \%$, while its base is formed by tall (Bromopsis taurica, Stipa erocaulis subsp. lithophila) or dense turf (Carex humilis, Festuca rupicola) hemicryptophytes, or low $(5-30 \mathrm{~cm}$ ) chamaephytes (dominated by Asperula supina, Cytisus polytrichum, Genista albida, G. depressa, Helianthemum stevenii, Pimpinella tragium subsp. lithophila, Sideritis taurica, Thymus callierii, Teucrium chamaedrys, T. jailae, Th. tauricus).

Although a number of obligate petrophytic species occur at all altitudes of the Crimean Mountains (Asphodeline 
lutea, Bromopsis taurica, Fepulaca rupacales, F. callierii, Helianthemum stevenii, Pimpinella lithophila, Stipa erocaulis subsp. lithophila, Thymus callierii, Teucrium chamaedrys and Th. tauricus), the communities of the lower belts are significantly different from the highlands and are rich in sub-Mediterranean elements, so we assigned them to a new alliance, Bromopsido tauricae-Asphodelinion tauricae. The petrophytic steppes of the previously mentioned alliance are formed on dense limestone outcrops of the lowaltitude belt of the Crimean Mountains and on the plain (Kerch and Tarkhankut peninsulas) in continental climatic conditions with an average temperature in July of $22-24^{\circ}$ and average precipitation of $300-550 \mathrm{~mm}$ (Ved 2000). They occur on dry, shallow, undeveloped and washed soils that accumulate in microdepressions of the relief (Dragan 2004). Petrophytic chamaephyte plants dominate in these communities (Artemisia lanuginosa (caucasica), Ephedra distachya, Fumana procumbens, Helianthemum stevenii, Jurinea stoechadifolia, Medicago rupestris, Pimpinella lithophila, Salvia scabijsifolia, Satureja taurica, Thymus callierii, Teucrium chamaedrys and Th. tauricus) with co-dominant graminoides (Bromopsis taurica, Festuca callieri, Melica ciliata, Stipa lessinfiana ssp. braunerii). It should be noted that we decided to distinguish the new alliance from the existing alliance Veronico multifidae-Stipion ponticae because the majority of the releves (73\%) were identified as being from the order Stipo pulcherrimae-Festucetalia pallentis. According to Arts. 2b \& 5 of the International Code of Phytosociological Nomenclature (Theurillat et al. 2020), we propose the holotypus of the new alliance as the Bromopsido tauricae-Asphodelinetum tauricae association type that was formerly considered (Didukh \& Mucina 2014) within the alliance Veronico multifidae-Stipion ponticae.

It should be mentioned that the characteristic species of the alliance Bromopsido tauricae-Asphodelinion tauricae are Asphodeline taurica, Medicago rupestris, Salvia scabiosifolia and Satureja taurica, which have sufficient indices of constancy (Table 1) and the characteristic species of the alliance Androsaco tauricae-Caricion humilis are Draba cuspidata, Stipa eriocaulis subsp. lithophila, Veronica taurica, Cerastium biebersteinii and Thymus tauricus, the evolution of which has been related to the Pleistocene glacial period (Didukh 1992). The species Carex humilis and Androsace villosa, as elements of the Pleistocene steppes, have isolated exclaves in the Crimea Mountains and can also be considered to be characteristic species of the alliance Androsaco tauricae-Caricion humilis.

The alliance Potentillo arenariae-Linion czernjajevii belonged to the order Festucetalia valesiacae, which was adopted in the "Prodrome of the vegetation of Ukraine" (Dubina et al. 2019), while Mucina et al. (2016) included it in the order Stipo pulcherrimae-Festucetalia pallentis.
These communities are classic petrophytic steppes communities, forming on peaks and slopes $\left(1-40^{\circ}\right)$ of low cliffs of river valleys that are subject to erosion, and Pontic limestone outcrops. Cover can reach $80-100 \%$, and Genista scythica, Jurinea stoechadifolia agg., Linum flavum agg., Pimpinella tragium subsp. lithophila, Stipa lessingiana and Thymus dimorphus dominate. In these communities there are many diagnostic species of the alliance Stipion lessingianae of the order Festucetalia valesiacae (Salvia nutans, Stipa lessingiana).

Communities of the alliance Centaureo carbonatiKoelerion talievii develop on dense outcrops of chalk, confined to gentle slopes $\left(2-30^{\circ}\right)$ of the riverbanks of the Central Russian Upland, where shallow soil can accumulate. The position of this alliance in the classification of steppe vegetation is entirely debatable. In the initial description, Romashchenko et al. (1996) included this alliance in the class Helianthemo-Thymetea, while Didukh \& Korotchenko (1997), Mucina et al. (2016) and Dubyna et al. (2019) classified it in the order Festucetalia valesiacae due to a significant share of steppe species in its floristic composition and an insignificant participation or absence of typical obligate calcephilous species, such as Artemisia hololeuca, A. nutans, A. salsoloides, Diplotaxis cretacea, Hyssopus cretaceus, Linaria cretacea, Matthiola fragrans, Scrophularia cretacea etc. Didukh et al. (2018) considered the alliance Centaureo carbonatae-Koelerion talievii, together with alliances of typical tomillares, to be in the order Thymo cretacei-Hyssopetalia cretacei but suggested that it may belong to the order Stipo pulcherrimae-Festucetalia pallentis. The dualism of this alliance is explained by its ecological and floristic features. In contrast to typical communities of the class Helianthemo-Thymetea, petrophytic steppes of the alliance Centaureo carbonatae-Koelerion talievii are characterized by a rich species composition (20-40 species) with a moderately dense cover, in which a significant proportion are steppe species (Festuca valesiaca, Medicago falcata, Salvia nutans, Stipa capillata, Teucrium polium), as well as facultative calcephilous plants of a wide-ranging ecology (Androsace villosa, Bupleurum falcatum, Carex humilis, C. pediformis, Hedysarum grandiflorum, Odontarrhena tortuosa, Onosma simplicissima, Psephellus marschallianus, Silene supina). Typical petrophytic chamaephyte plants (Asperula tephrocarpa, Helianthemum canum, Pimpinella tragium subsp. lithophila, Thymus calcareus), together with steppe species, are dominant. The similarity of floristic composition and ecological features, as well as the structural likeness of this alliance to the alliance Potentillo arenariae-Linion czernjajevii allows us to consider them to be vicarious and syntaxonomically related.

In general, communities of the order Stipo pulcherrimae-Festucetalia pallentis are characterized by different 
ecological conditions than surrounding communities, and the main factor is their confinement to outcrops of calcareous rocks, which determine the chemical properties, high thermal regime and lack of soil moisture, which causes these communities to adapt physiologically to dryness. Analyzing the distribution of the characterized alliances in geographical terms, it can be concluded that, within Ukraine (from west to east), their "neighborhood" changes from the steppe communities of Cirsio-Brachypodion, Festucion valesiacae, Stipion lessingianae, Veronico multifidae-Stipion ponticae on developed soils, to ElynoSeslerietea, Sedo-Scleranthetea (Alysso-Sedetalia), Helianthemo-Thymetea, Drypidetea on petrophytic substrata. All these surrounding communities affect the specific structure of the alliances of the order Stipo pulcherrimae-Festucetalia pallentis, which determines their specificity.

\section{Conclusions}

Calcareous steppes of the order Stipo pulcherrimae-Festucetalia pallentis in Ukraine are diverse. This phenomenon is caused by the types of petrophytic substrata (chalk, gypsum, limestone, and shale), their geographical location, which determines the chemical properties, structure, capacity, humidity deficit and nutrient deficiency of the soils. These factors determine the specificity of plant communities, which often have a loose structure, as well as terrestrial and underground adaptations to such conditions. The coenotic base consists of chamaephytes and hemicryptophytes with a strong root system, but oftentimes the co-dominants are grass. A characteristic feature of the flora is high systematic differentiation into small races, which are expressed in increased endemism for certain regions and indicates the distinctive nature of the development of these communities.

Based on a critical analysis of the literature, processing of phytosociological relevés, comparative assessment of coenoses by floristic composition and indicators of the main environmental factors, the syntaxonomic structure and patterns of differentiation at the level of alliances were established. The order Stipo pulcherrimae-Festucetalia pallentis in Ukraine is represented by seven alliances (Diantho lumnizeri-Seslerion albicantis, Genisto tetragonae-Seselion peucedanifoliae, Galio campanulati-Poion versicoloris, Bromopsido tauricae-Asphodelinion tauricae, Androsaco tauricae-Caricion humilis, Potentillo arenariae-Linion czernjajevii, Centaureo carbonatae-Koelerion talievii) for which the relevant characteristics are given. Communities of calcareous petrophytic steppes of the lower belts of the Crimean Mountains were therefore allocated to a new alliance Bromopsido tauricae-Aspho- delinion tauricae. The results indicate the uniqueness and great scientific value of petrophytic steppes, which requires further in-depth study of their structure and taxonomic composition.

\section{Acknowledgements}

We are sincerely grateful to Grzegorz Swacha and Ilona Knollova for the data from Central Europe (Poland, Hungary, Slovak Republic) extracted from the EVA Database (including data from the Polish database) and Pavel Pinzaru for the data from Moldova. We are grateful to the Editor-in-Chief Urban Šilc and two anonymous reviewers for valuable comments and suggestions. We also thank Martin Cregeen, Gabrielle Oke and Deborah Oke for linguistic improvements of the manuscript. The research was carried out within the projects "Functional, syntaxonomical and phylogenetic diversity of Ukrainian steppes as a basis for an evaluation of their ecosystem services" and "Grass habitats of Ukraine of European importance: current status, scale of losses and conservation strategy in the context of global climate change and anthropogenic transformation of the environment".

Yakiv Didukh (1) https://orcid.org/0000-0001-7619-0283 Iuliia Vasheniak (D) https://orcid.org/0000-0003-1020-3007 Olga Chusova (1) https://orcid.org/0000-0002-8081-9918

\section{References}

Aćić, S., Šilc, U., Petrović, M., Tomović, G. \& Dajić Stevanović, Z. 2015: Classification, ecology and biodiversity of Central Balkan dry grasslands. Tuexenia 35: 329-353.

DOI: https://doi.org/10.14471/2015.35.007

Vassilev, K, Apostolova, I. 2013: Bulgarian steppic vegetation - an overview. In: Baumach, H., Pfützenreuter, S. (eds) Steppenlebensräume Europas - Gefährung, Erhaltungsmassnahmen und Schutz.: 191-200.

Chytrý, M., Hennekens, S. M., Jiménez-Alfaro, B., Knollová, I., Dengler, J., Jansen, F., Landucci, F., Schaminée, J.H., Aćić, S., Agrillo, E., Ambarli, D., Angelini, P., Apostolova, I., Attorre, F., Berg, C., Bergmeier, E., Biurrun, I., Botta-Dukát, Z., Brisse, H., Campos, J.A., Carlón, L., Čarni, A., Casella, L., Csiky, J., Ćušterevska, R., Dajić Stevanović, Z., Danihelka, J., deBie, E., deRuffray, P., deSanctis, M., Dickoré, W.B., Dimopoulos, P., Dubyna, D., Dziuba, T., Ejrnaes, R., Ermakov, N., Ewald, J., Fanelli, G., Fernández-González, F., Fitzpatrick, Ú., Font, X. \& García 2016: European Vegetation Archive (EVA): An integrated database of European vegetation plots. Applied Vegetation Science 19 (1): 173-180. doi:10.1111/avsc.12191

Chytrý, M., Tichý, L., Holt, J. \& Botta-Dukát, Z. 2002: Determination of diagnostic species with statistical fidelity measures. Journal of Vegetation Science. 13: 79-90. DOI: https://doi. org/10.1111/j.1654-1103.2002.tb02025.x

Chytrý, M. (ed.) 2007: Vegetace České Republiky 1. Travinná a keříčková vegetace. Academia, Praha, 526 pp. (in Czech). 
Dengler, J., Becker, T., Ruprecht, E., Szabó, A., Becker, U., Beldean, M., Bita-Nicolae, C., Dolnik, C., Goia, I., Peyrat, J., Sutcliffe, L.M.E., Turtureanu, P.D. \& Uğurlu, E. 2012: Festuco-Brometea communities of the Transylvanian Plateau (Romania) - a preliminary overview on syntaxonomy, ecology, and biodiversity. Tuexenia 32: 319-359.

Didukh, Y. P. 1981: Tomilyary Hirskoho Krymu. Ukrainskyi botanichnyi zhurnal 38 (4): 18-23 (in Ukrainian).

Didukh, Y. P. 1992: Rastitelnyi pokrov Gornogo Kryma. Naukova dumka, Kyiv. 256 pp. (in Russian).

Didukh, Y. P. \& Shelyag-Sosonko, Y. R. 2003: Geobotanichne rayonuvannia Ukrainy ta sumizhnykh terytoriy. Ukrainskyi botanichnyi zhurnal 60 (1): 6-17 (in Ukrainian).

Didukh, Y. P. 2011: The ecological scales for the species of Ukrainian flora and their use in synphytoindication. Phytosociocentre, Kyiv, 176 pp.

Didukh, Y. P. 2012: Osnovy bioindykatsii. Naukova dumka, Kyiv. 342 pp. (in Ukrainian).

Didukh, Y. P. \& Mucina, L. 2014: Validation of names of some syntaxa of the Crimean vegetation. Lazaroa 35: 181-190. DOI: https://doi. org/10.5209/rev_LAZA.2014.v35.47069

Didukh, Y. P., Chusova, O. \& Demina, O. 2018: Syntaxonomy of chalk outcrop vegetation of the order Thymo cretacei-Hyssopetalia cretacei. Hacquetia 17(1): 85-109. DOI: https://doi.org/10.1515/ hacq-2017-0013

Didukh, Y. P., Vasheniak, Y. A. 2018: Vegetation of limestone outcrops in Western and Central Podilla (Ukraine). Tuexenia 38: 1-26. DOI: https://doi.org/10.14471/2018.38.023

Didukh, Y. P. 2019: Epifitni briotsenozy v biotopakh nemoralnykh lisiv. Ukrainskyi botanichnyi zhurnal 60 (1): 132-143 (in Ukrainian). DOI: https://doi.org/10.15407/ukrbotj76.02.132

Dragan, N. A. 2004: Pochvennye resursy Kryma. Dolya, Simferopol, 208 pp. (in Russian).

Dubyna, D. V., Dziuba, T. P., Iemelianova, S. M., Bagrikova, O. V., Borisova, O. V., Borsukevych, L. M., Vynokurov, D. S., Gapon, S. V., Davydov, D. A., Dvoretskyi, T. V., Didukh, Y. P., Zhmud, O. I., Kozyr, M. S., Konishchuk, V. V., Kuzemko, A. A., Pashkevych, N. A., Ryff, L. E., Solomakha, V. A., Felbaba-Klushyna, L. M., Fitsailo, T. V., Chorna, G. A., Chorney, I. I., Shelyag-Sosonko, Y. R., Yakushenko,

D. M. 2019: Prodrome of the vegetation of Ukraine. Naukova dumka, Kyiv, 747 pp. (in Ukrainian).

Dubyna, D. V., Ennan, A. A.-A., Dziuba, T. P., Vakarenko, L. P., Shykhaleyeva, G. M. 2019: New syntaxa of steppe vegetation of the Kuialnyk Estuary (Odesa Region, Ukraine). Ukrainskyi botanichnyi zhurnal 76 (3): 220-235 (in Ukrainian). DOI: https://doi.org/10.15407/ ukrbotj76.03.220

Euro+Med 2006: Euro+Med PlantBase - the information resource for Euro-Mediterranean plant diversity. Online: http://ww2.bgbm.org/ EuroPlusMed/22.10.2017 [11.05.2020].

Gulisashvili, V. Z., Makhatadze, L. B., Prylypko, L. I. 1975: Rastytelnost Kavkaza. Nauka, Moscow, 233 pp. (in Russian).

Grime, J. P. 1977: Evidence for the Existence of Three Primary Strategies in Plants and Its Relevance to Ecological and Evolutionary Theory. The American Naturalist 111 (982): 1169-1194.
Hegedüšová Vantarová, K. \& Škodová, I. (eds.) 2014: Vegetácia Slovenska. Rastlinné spoločenstvá Slovenska 5. Travinno-bylinná vegetácia. Veda1 581 pp. (in Slovakian).

Herenchuk, K. I. 1979: Pryroda Ternopilskoi oblasti. Vyshcha shkola, Lviv, 167 pp. (in Ukrainian).

Herenchuk, K. I. 1980: Pryroda Khmelnytskoi oblasti. Vyshcha shkola, Lviv, 152 p.p. (in Ukrainian).

Herenchuk, K. I. 1981: Pryroda Zakarpatskoi oblasti. Vyshcha shkola, Lviv, 156 pp. (in Ukrainian).

Hill, M. O. 1979: TWINSPAN - A FORTRAN program for arranging multivariate data in an ordered two-way table by classification of the individuals and attributes. Cornel University, Ithaca, NY, 90 pp.

Janišová, M. (ed.) 2007: Travinnobylinná vegetácia Slovenska elektronický expertný systém na identifikáciu syntaxónov. Botanický ústav SAV, Bratislava, 263 pp. (in Slovakian).

Janišová, M. \& Dúbravková, D. 2010: Formalized classification of rocky Pannonian grasslands and dealpine Sesleria-dominated grasslands in Slovakia using hierarchical expert system. Phytocoenologia 40 (4): 267-291. DOI: https://doi.org/10.1127/0340-269X/2010/0040-0444

Kącki, Z. \& Śliwiński, M. 2012: The Polish Vegetation Database: structure, resources and development. Acta Societatis Botanicorum Poloniae 81 (2): 72-79. DOI: https://doi.org/10.5586/asbp.2012.014

Kącki, Z., Czarnecka, M., Swacha, G. 2013: Statistical determination of diagnostic, constant and dominant species of the higher vegetation units of Poland. Monogr. Bot., Vol.103, 267 pp.

Janišová, M., Bauer, N., Botta-Dukát, Z., Čarni, A., Chytrý, M., Coldea, G., Csiky, J., Dúbravková, D., Fenesi, A., Igic, R., Kącki, Z., Kish, R., Korzeniak, J., Krstivojevic, M., Krstonošić, D., Bita-nicolae, C., Rédei, T., Ruprecht, E., Stančić, Zvjezdana, Škodová, I., Tichý, L.\& Willner, W. 2014: Rocky grassland vegetation (Stipo-Festucetalia) of the Pannonian Basin and the Carpathian Mts - biogeographical patterns revealed by semi-supervised classification. - Oral presentation at the $23^{\text {rd }}$ Workshop of European Vegetation Survey Ljubljana, Slovenia.

Kamelin, R. V. 1979: Kukhistanskiy okrug gornoy Sredney Azii. Nauka, Leningrad, 117 pp. (in Russian).

Khodosovtsev, O. Y. 2002: Likhenotsenotychni elementy u likhenoflori kamyanystykh vidslonen Krymskoho pivostrova. Y. D. Kleopov ta problemy botanichnoi nauky. Fitosotsiotsentr, Kyiv: 299-314 (in Ukrainian).

Klokov, M. V. 1973: Raznoobrazie v rode timyanov Thymus L. na territorii Sovetskogo Soyuza. Naukova dumka, Kyiv, 192 pp. (in Russian).

Klokov, M. V. 1974: Geograficheskaya rasa kak istoricheskoe yavlenie. Pryrodnaya obstanovka i fauny proshlogo 8: 105-111 (in Russian).

Kondracki, J. 1965: Geografia fizyczna Polski. Państwowe Wyd. Naukowe, 463 pp. (in Polish)

Korotchenko, I. A. \& Didukh, Y. P. 1997: The steppe vegetation of the southern part of the LeftBank Forest-Steppe of the Ukraine. II. Class Festuco-Brometea. Ukrainskyi fitotsenolohichnyi zbirnyk, Ser. A 1 (6): 20-39 (in Ukrainian). 
Korotchenko, I. A. 2004: Stepova roslynnist' pivdennoi chastyny Natsional'nogo pryrodnogo parku "Podil'ski Tovtry". Naukovyi visnyk Chernivetskoho universytetu. Biolohiia (Biolohichni systemy) 223: 197-221 (in Ukrainian).

Korzhenevskii, V. V. 1990: Sintaksonomicheskii sostav rastitel'nosti flyshebogo nizkogor'ya yugo-istochnogo kryma. Sborn. Nauch. Trud. yalta 110: 80-90 (in Russian).

Krasova, O \& Smetana, M. 1999: Stepova roslynnist balky kobylnoi Ukrainskyi fitotsenolohichnyi zbirnyk, Ser. A 1-2 (12-13): 21-30 (in Ukrainian).

Krytsjka, L. I. 2010: Osnovni rysy rozvytku flory stepiv ta vapnyakovykh vidslonen Pravoberezhnoho Zlakovoho Stepu (Pivnichno-Zakhidne Prychornomor'ya). Proceedings of the Natural Museum of Natural History 8: 89-98 (in Ukrainian).

Kukovytsia, H. S., Movchan, Y. I., Solomakha, V. A. \& Shelyag-Sosonko, Y. R. 1994: Syntaksonomiya luchnykh stepiv Zakhidnogo Podillya. Ukrainskyi botanichnyi zhurnal 51 (2-3): 35-48 (in Ukrainian).

Kuzemko A. A. 2012: Ukrainian Grasslands Database. Biodiversity \& Ecology 4: 430-430. DOI: https://doi.org/10.7809/B-E.00217

Lavrenko, E. M. 1940: Stepi SSSR. Rastitelnost SSSR. V.2.: 1-265 (in Russian).

Lavrenko, E. M. 1973: O razvitii nekotorykh tsenoticheskikh tipov flory Drevnego Sredizemya v svyazi s alpiyskim orogenezom. Trudy Tashkentskoho unyversyteta 187: 17-27 (in Russian).

Lavrenko, E. M. 1980: Petrofitnaia rastitelnost v lesostepi i stepi (vne gornykh system). Rastitelnost Evropeiskoi chasti SSSR: 281-284 (in Russian).

Lavrenko, E. M., Karamysheva, E. M., Nikulina, R. I. 1991: Stepi Evrazii. Leningrad, Nauka. 146 pp. (in Russian).

Litvinov, D. I. 1891: Geobotanicheskie zametki o flore Evropeyskoy Rossii. Byulleten Moskovskogo obshchestva ispytateley prirody 4 (3): 322-434 (in Russian).

Mucina, L., Bültmann, H., Dierßen, K., Theurillat, J.-P., Dengler, J., Čarni, A., Šumberová, K., Raus, T., di Pietro, R., Gavílan García, R., Chytrý, M., Yakushenko, D., Schaminée, J. H .J., Bergmeier, E., Santos Guerra, A., Daniëls, F. J. A., Ermakov, N., Valachovic, M., Pignatti, S., Rodwell, J. S., Pallas, J., Capelo, J., Weber, H. E., Lysenko, T., Didukh, Y. P., Capelo, J., Weber, H., Solomesh, A., Dimopolous, P., Aguiar, C., Freitag, H., Hennekens, S. M. \& Tichý, L. 2016: Vegetation of Europe: hierarchical floristic classification system of vascular plant, bryophyte, lichen and algal communities. Applied Vegetation Science 19 (Supplement 1): 3-264. DOI: https://doi.org/10.14471/2018.38.02310.1111/avsc.12257

Mosyakin, S. L. \& Fedoronchuk, M. M. 1999: Vascular Plants of Ukraine. A nomenclature Checklist. Kiev, 345 pp.

Onyshchenko, V. A. 2001: Roslynnist' karbonatnykhvidslonen' pryrodnogozapovidnyka "Medobory". Ukrainskyi fitotsenolohichnyi zbirnyk Ser. A, 1 (17): 86-104 (in Ukrainian).

Pinzaru, P. 1997: Genisto-Seselion peucedanifolii - alianta noua in vegetatia calcarelor Sarmatianului Mediu din Republica Moldova. Dep. Chisinaua 1469-M.: 29 p. (in Romanian).

Pinzaru, P. 2006: Tipurile asociațiilor noi din vegetația de stîncării din interfluviu NistruPrut // Aspecte ştiințifico-practice a dezvoltării durabile a sectorului forestier din Republica: 242-250 (in Romanian).
Pop, I. 1968: Conspectul associstiilor ierboase de pe masivele calcaroase din cuprinsul Carpatilor Romaneşti. Contribuții Botanice 12: $267-273$ (in Romanian).

R Core Team 2013: A language and environment for statistical computing. R Foundation for Statistical Computing, Vienna, Austria. Online: http: // www.R-project.org/

Romaschenko, K., Didukh, Y., Solomakha, V. 1996: Syntaksonomia klasu Helianthemo-Thymetea cl. nov. roslynnosti kreidyanykh vidslonen pivdenno-shidnoi Ukrainy. Ukrainskyi fitotsenolohichnyi zbirnyk, Ser. A, 1. -49-62 (in Ukrainian).

Rushchuk, A. D., Pinzaru, P. Y., Rushchuk, V. D., Khlebnikov, V. F. 2005: Soyuz Genisto tetragonae-Seselion peucedanifoliae Pinzaru 1997 na territorii levoberezhya Dnestra v Moldove. Geoekologicheskie i bioekologicheskie problemyi severnogo Prichernomorya: 63-66 (in Romanian).

StatSoft Inc. 2010: Electronic statistic textbook. Statsoft, Tusla. Online: http://www.statsoft.com/text-book/stathme.html

Takhtandzhyan, A. L. 1937: Kserofitnaia rastitelnost skeletnykh gor Armenii. Trudy Armianskogo filiala AN SSSR. Ser. Biol. 2: 24-38 (in Russian).

Takhtandzhyan, A. L. 1940: Botaniko-geograficheskiy ocherk Armenii. Trudy Botanicheskogo instituta Armianskogo filiala AN SSSR 2: $1-180$.

Tichý, L \& Chytrý, M. 2006: Statistical determination of diagnostic species for site groups of unequal size. Journal of Vegetation Science 17: 809-818. DOI: https://doi.org/10.1111/j.1654-1103.2006. tb02504.x

Ved, I. P. 2000: Klimaticheskiy atlas Kryma. Tavria plus, Simferopol, 119 pp. (in Russian).

Theurillat, J.-P., Willner, W., Fernándes-González, F., Bültman, H., Čarni, A., Gigante, D., Mucina, L., Weber, H. 2020. International Code of Phytosociological Nomenclature. $4^{\text {th }}$ edition. Applied Vegetation Science. DOI: https://doi.org/org/10.1111/avsc.12491

Willner, W., Kuzemko, A. A., Dengler, J., Chytrý, M., Bauer, N., Becker, T., Biță-Nicolae, C., Botta-Dukat, Z., Čarni, A., Csiky, J., Igić, R., Kącki, Z., Korotchenko. I., Kropf, M., Krzystojević Ćuk, M., Krstonošić, D., Rédei, T., Ruprecht, E., Schratt-Ehrendorfer, L., Semenishchenkov, Iu., Stančic, Z., Vasheniak, Iu., Vynokurov, D. \& Janišová, M. 2017: A higher-level classification of the Pannonian and Western Pontic steppe grasslands (Central and Eastern Europe) Applied Vegetation Science 20 (1): 143-158. DOI: https://doi. org/10.1111/avsc. 12265

Willner, W. 2020: What is an alliance? Vegetation Classification and Survey 1: 139-144. DOI: https://doi.org/10.3897/VCS/2020/56372

Yaroshenko, P. D. 1956: Smeny rastitelnogo pokrova Zakavkazya v ikh svyazi s pochvenno-klimaticheskimi izmeneniyami i deyatelnostyu cheloveka. Izdatelstvo AN URSR, Moscow, Leningrad, 242 pp. (in Russian).

Zaverukha, B. V. 1985: Flora Volyno-Podolii i ee genesis. Naukova dumka, Kyiv, 190 pp. (in Russian).

Zólyomi, B. 1966: Neue Klassifi kation der Felsen-vegetation im Pannonischen Raum und der angrenzenden Gebiete. Bot. Közlem. 53/1: 49-54. 
Table 2: Synoptic table of petrophytic calcareous communities of Ukraine and adjacent territories, showing the constancy of species, expressed by their percentage frequency in the respective eight-level clusters. Shaded species are ranked by decreasing constancy: dark shading $\geq 50 \%$, light shading $\geq 25 \%$. Phi coefficient values are not shown but species with a phi-value greater than 0.25 are accepted as differential for the alliances. Species of each syntaxon with a $15 \%$ constancy and less, as well as other taxa with a $15 \%$ constancy and less, are not shown in the table.

Tabela 2: Sinoptična tabela petrofitskih združb na apnencu v Ukrajini in sosednjih območjih. Prikazana je stalnost vrst kot odstotna frekvenca v posameznem klastru. Zasenčene vrste so razporejene po padajoči stalnosti: temno zasenčeno $\geq 50 \%$, svetlo zasenčeno $\geq 25 \%$. Vrednosti phi koeficienta niso prikazane, a so vrste $s$ phi vrednostjo, večjo od 0,25 , opredeljene kot razlikovalnice zvez.

Značilne vrste za posamezen sintakson s stalnostjo $15 \%$ ali manj in vse ostale vrste s stalnostjo $15 \%$ ali manj, v tabeli niso prikazane.

\begin{tabular}{|c|c|c|c|c|c|c|c|c|}
\hline No. of relevés & 14 & 47 & 45 & 173 & 26 & 36 & 124 & 23 \\
\hline Cluster No. & 1 & 2 & 3 & 4 & 5 & 6 & 7 & 8 \\
\hline TWINSPAN Group & \multicolumn{2}{|c|}{ A } & \multicolumn{2}{|c|}{$\mathrm{B}$} & \multicolumn{2}{|c|}{$\mathrm{C}$} & $\mathrm{D}$ & $\mathrm{E}$ \\
\hline \multicolumn{9}{|c|}{ All. Bromo pannonici-Fectucion csikhegyensis } \\
\hline Sesleria heuflerana & 100 & . & 4 & 10 & . & . & . & . \\
\hline Seseli osseum & 64 & . & . & . & . & . & . & . \\
\hline Asplenium trichomanes & 57 & 15 & . & 3 & . & . & . & . \\
\hline Galium mollugo & 57 & 13 & 16 & 16 & . & . & 3 & . \\
\hline Saxifraga paniculata & 50 & 19 & . & . & . & . & . & . \\
\hline Sorbus aria & 43 & . & . & . & . & . & . & . \\
\hline Pulsatilla vulgaris subsp. grandis & 43 & . & 4 & . & . & . & . & . \\
\hline Aconitum anthora & 36 & . & . & . & . & . & . & . \\
\hline Thalictrum foetidum & 29 & . & . & . & . & . & . & . \\
\hline \multicolumn{9}{|c|}{ All. Diantho lumnitzeri-Seslerion albicantis } \\
\hline Allium lusitanicum & . & 68 & 18 & 21 & . & . & . & . \\
\hline Poa compressa & . & 64 & 2 & 15 & . & . & 3 & 13 \\
\hline Campanula rotundifolia & . & 51 & . & 2 & . & . & . & . \\
\hline Galium album & . & 51 & 2 & . & 12 & 42 & 2 & . \\
\hline Thymus pulegioides & . & 49 & . & . & . & . & . & . \\
\hline Pilosella officinarum & . & 49 & 18 & 5 & . & . & . & 9 \\
\hline Sanguisorba minor agg. & . & 49 & 7 & 3 & 19 & 14 & 44 & . \\
\hline Juniperus communis & 7 & 40 & . & . & . & . & . & . \\
\hline Seseli libanotis & 14 & 45 & . & 10 & . & . & . & . \\
\hline Achillea millefolium agg. & . & 45 & 7 & 17 & 4 & 6 & 5 & 30 \\
\hline Centaurea stoebe agg. & . & 38 & 20 & 42 & . & . & 2 & 13 \\
\hline Arabis hirsuta & . & 36 & . & 6 & . & . & . & . \\
\hline Silene nutans agg. & . & 36 & 11 & 2 & . & . & 1 & . \\
\hline Hypericum perforatum & 7 & 34 & 7 & 5 & 8 & 6 & 1 & 9 \\
\hline Galium cracoviense & . & 34 & . & . & . & . & . & . \\
\hline Linum catharticum & . & 34 & 11 & 1 & . & . & . & . \\
\hline Pimpinella saxifraga & . & 34 & 31 & 3 & . & . & 2 & . \\
\hline Artemisia campestris agg. & . & 34 & 20 & 31 & . & . & 2 & 4 \\
\hline Erysimum odoratum & . & 32 & 4 & 5 & . & . & . & . \\
\hline Sedum sexangulare & . & 30 & . & 5 & . & . & . & . \\
\hline Potentilla pusilla & . & 28 & . & . & . & . & . & . \\
\hline Medicago lupulina & . & 28 & . & 6 & . & . & . & . \\
\hline Fragaria vesca & . & 26 & . & . & . & . & . & . \\
\hline Helianthemum nummularium agg. & 7 & 26 & 18 & 1 & 12 & 19 & 4 & . \\
\hline \multicolumn{9}{|c|}{ Common differential species in group $\mathbf{A}$} \\
\hline Asplenium ruta-muraria & 79 & 77 & . & 23 & . & . & . & . \\
\hline Euphorbia cyparissias & 50 & 89 & 24 & 60 & . & . & . & 4 \\
\hline Festuca pallens & 71 & 83 & 11 & 10 & . & . & . & . \\
\hline Jovibarba globifera agg. & 71 & 91 & . & . & . & . & . & . \\
\hline
\end{tabular}




\begin{tabular}{|c|c|c|c|c|c|c|c|c|}
\hline No. of relevés & 14 & 47 & 45 & 173 & 26 & 36 & 124 & 23 \\
\hline \multicolumn{9}{|c|}{ All. Genisto tetragonae-Seselion peucedanifoliae } \\
\hline Anthericum ramosum & 21 & 9 & 89 & 24 & . & . & 5 & 13 \\
\hline Inula ensifolia & 21 & 6 & 76 & 19 & 23 & 25 & 8 & . \\
\hline Thalictrum minus & . & . & 49 & 8 & 19 & 17 & 10 & 57 \\
\hline Aster amellus & . & . & 42 & 15 & . & 6 & 5 & 4 \\
\hline Adonis vernalis & . & . & 33 & 5 & 4 & 3 & 9 & 22 \\
\hline Anemone sylvestris & . & . & 29 & . & . & . & . & 4 \\
\hline Echium vulgare & . & 9 & 29 & 17 & . & . & 1 & . \\
\hline Hieracium virosum & . & . & 29 & 9 & . & 3 & 6 & 22 \\
\hline Campanula glomerata & . & . & 27 & . & . & . & 2 & . \\
\hline Astragalus pseudoglaucus & . & . & 27 & . & . & . & 3 & . \\
\hline Lembotropis nigricans & . & . & 27 & 6 & . & . & . & . \\
\hline Pulsatilla pratensis & . & . & 27 & 2 & . & . & 2 & 4 \\
\hline Taraxacum serotinum & . & . & 27 & . & . & . & 9 & 4 \\
\hline \multicolumn{9}{|c|}{ All. Galio campanulati-Poion versicoloris } \\
\hline Sedum acre & . & 43 & 4 & 60 & 15 & . & 2 & . \\
\hline Clinopodium acinos & . & 57 & 11 & 47 & 8 & 11 & 2 & 4 \\
\hline Arenaria serpyllifolia agg. & . & 32 & 4 & 46 & 15 & 17 & 15 & . \\
\hline Botriochloa ischaemum & . & . & 22 & 32 & 12 & . & 16 & 4 \\
\hline Poa versicolor & . & . & 4 & 29 & . & . & . & . \\
\hline Alyssum alyssoides & . & 2 & . & 25 & . & . & 3 & . \\
\hline Elytrigia intermedia agg. & . & . & 16 & 25 & . & . & 1 & 13 \\
\hline \multicolumn{9}{|c|}{ Common differential species in group B } \\
\hline Asperula cynanchica & . & 19 & 53 & 58 & . & . & 25 & . \\
\hline Potentilla incana & 14 & 34 & 78 & 60 & . & . & 36 & 9 \\
\hline Salvia verticillata & . & 30 & 40 & 28 & . & . & 1 & 4 \\
\hline Thymus pannonicus agg. & 7 & 4 & 40 & 54 & . & . & 8 & . \\
\hline \multicolumn{9}{|c|}{ All. Bromopsido tauricae-Asphodelinion tauricae } \\
\hline Fumana procumbens & . & . & . & . & 58 & 3 & $\cdot$ & . \\
\hline Iris pumila & . & . & . & 1 & 58 & . & 10 & 13 \\
\hline Leontodon biscutellifolius & . & . & 11 & 1 & 54 & 11 & 10 & . \\
\hline Jurinea roegneri & . & . & . & . & 50 & 6 & . & . \\
\hline Onobrychis arenaria agg. & . & . & 11 & 1 & 50 & . & 3 & 30 \\
\hline Veronica multifida & . & . & . & . & 46 & . & . & . \\
\hline Agropyron ponticum & . & . & . & . & 46 & . & . & . \\
\hline Carex caryophyllea & . & 9 & . & . & 42 & 8 & 1 & . \\
\hline Odontarrhena muralis & . & . & 9 & . & 42 & 17 & 2 & . \\
\hline Onosma rigida & . & . & . & . & 42 & . & . & . \\
\hline Eryngium campestre & . & . & 27 & 11 & 38 & . & 23 & 9 \\
\hline Asphodeline taurica & . & . & . & . & 38 & . & . & . \\
\hline Asperula tenella & . & . & . & . & 35 & 8 & 2 & . \\
\hline Poa sterilis & . & . & . & . & 31 & 6 & 6 & . \\
\hline Satureja taurica & . & . & . & . & 31 & . & . & . \\
\hline Phlomis herba-venti agg. & . & . & 2 & . & 31 & 22 & 3 & . \\
\hline Stipa pontica & . & . & . & . & 27 & . & . & . \\
\hline Medicago rupestris & . & . & . & . & 27 & . & . & . \\
\hline Galium glaucum & . & . & 4 & 18 & 27 & 11 & 1 & . \\
\hline Melica transsilvanica & 7 & 11 & 4 & 15 & 27 & 14 & 5 & . \\
\hline \multicolumn{9}{|c|}{ All. Androsaco tauricae-Caricion humilis } \\
\hline Anthyllis vulneraria agg. & . & 49 & 9 & 5 & 23 & 72 & . & . \\
\hline Potentilla recta agg. & . & . & 4 & 3 & 8 & 69 & 19 & . \\
\hline
\end{tabular}




\begin{tabular}{|c|c|c|c|c|c|c|c|c|}
\hline No. of relevés & 14 & 47 & 45 & 173 & 26 & 36 & 124 & 23 \\
\hline Thymus tauricus & . & . & . & . & 19 & 67 & . & . \\
\hline Filipendula vulgaris & . & . & 29 & . & 8 & 64 & 1 & 26 \\
\hline Androsace villosa agg. & . & . & . & . & . & 58 & . & 43 \\
\hline Stipa eriocaulis subsp. lithophila & . & . & . & . & 4 & 56 & . & . \\
\hline Koeleria brevis agg. & . & . & . & . & 15 & 50 & 19 & . \\
\hline Veronica taurica & . & . & . & . & . & 44 & . & . \\
\hline Alyssum montanum & . & . & 2 & 5 & 8 & 42 & 2 & . \\
\hline Cerastium biebersteinii & . & . & . & . & . & 39 & . & . \\
\hline Tephroseris integrifolia subsp. jailicola & . & . & . & . & . & 36 & . & . \\
\hline Pulsatilla halleri subsp. taurica & . & . & . & . & 4 & 36 & . & . \\
\hline Onobrychis jailae & . & . & . & . & 4 & 36 & . & . \\
\hline Iberis saxatilis & . & . & . & . & 8 & 36 & . & . \\
\hline Convolvulus calvertii subsp. calvertii & . & . & . & . & 23 & 31 & . & . \\
\hline Elytrigia strigosa & . & . & . & . & . & 28 & . & . \\
\hline Alopecurus vaginatus & . & . & . & . & . & 28 & . & . \\
\hline Euphorbia agraria & . & . & 11 & . & 4 & 28 & 4 & . \\
\hline Cytisus hirsutus agg. & . & . & . & . & . & 25 & . & . \\
\hline \multicolumn{9}{|c|}{ Common differential species in group $\mathrm{C}$} \\
\hline Asperula supina & . & . & . & . & 38 & 64 & . & . \\
\hline Cruciata taurica & . & . & . & . & 31 & 39 & . & . \\
\hline Bromopsis taurica & . & . & . & . & 88 & 97 & . & . \\
\hline Euphorbia petrophila agg. & . & . & . & . & 65 & 25 & 3 & . \\
\hline Genista scythica & . & . & . & . & 27 & 81 & 23 & 4 \\
\hline Helianthemum stevenii & . & . & . & . & 73 & 83 & . & . \\
\hline Minuartia setacea agg. & . & . & 9 & 21 & 27 & 28 & 23 & . \\
\hline Paronychia cephalotes & . & . & . & . & 46 & 75 & 8 & . \\
\hline Potentilla astracanica agg. & . & . & . & . & 69 & 39 & 27 & . \\
\hline Thymus dimorphus & . & . & . & 2 & 54 & 50 & 46 & . \\
\hline Scorzonera crispa & . & . & . & . & 35 & 56 & . & . \\
\hline Sideritis taurica & . & . & . & . & 38 & 56 & . & . \\
\hline \multicolumn{9}{|c|}{ All. Potentillo arenariae-Linion czernjajevii } \\
\hline Odontarrhena tortuosa & . & . & . & . & 12 & . & 49 & . \\
\hline Stipa lessingiana & . & . & 2 & . & 12 & . & 42 & . \\
\hline Poa bulbosa & . & . & . & 17 & 12 & . & 40 & . \\
\hline Jurinea stoechadifolia agg. & . & . & 16 & $\cdot$ & 31 & . & 37 & . \\
\hline Astragalus pallescens & . & . & . & . & . & . & 31 & 9 \\
\hline Linum austriacum agg. & . & . & . & . & 23 & . & 31 & 4 \\
\hline Linum flavum agg. & . & 2 & 13 & 10 & 27 & . & 31 & 65 \\
\hline Cephalaria uralensis & . & . & . & 9 & . & . & 31 & 4 \\
\hline \multicolumn{9}{|c|}{ All. Centaureo carbonatae-Koelerion talievii } \\
\hline Gypsophila oligosperma & . & . & . & . & . & . & . & 83 \\
\hline Salvia nutans & . & . & 18 & 1 & 4 & . & 52 & 83 \\
\hline Polygala sibirica & . & . & 20 & 1 & . & . & 3 & 74 \\
\hline Astragalus austriacus & . & . & 27 & 1 & . & . & 2 & 70 \\
\hline Euphorbia seguieriana & . & . & 11 & 7 & 4 & 3 & 31 & 65 \\
\hline Bromopsis riparia & . & . & . & 1 & . & . & 44 & 57 \\
\hline Viola ambigua & . & . & 9 & 7 & . & 17 & 28 & 48 \\
\hline Thesium arvense & . & . & 7 & 1 & 35 & 3 & 19 & 48 \\
\hline Nonea pulla agg. & . & . & 4 & 2 & . & . & 2 & 43 \\
\hline Koeleria macrantha & . & . & 7 & 27 & 15 & 17 & 20 & 43 \\
\hline Potentilla humifusa & . & . & . & . & . & 6 & . & 43 \\
\hline
\end{tabular}




\begin{tabular}{|c|c|c|c|c|c|c|c|c|}
\hline No. of relevés & 14 & 47 & 45 & 173 & 26 & 36 & 124 & 23 \\
\hline Linum hirsutum agg. & . & . & . & 1 & 12 & . & 3 & 43 \\
\hline Veronica spicata agg. & . & 17 & 24 & 27 & . & 11 & 13 & 39 \\
\hline Euphorbia nicaeensis agg. & . & $\cdot$ & 24 & 3 & 8 & $\cdot$ & 37 & 35 \\
\hline Thymus calcareus & . & . & . & . & . & . & 4 & 35 \\
\hline Reseda lutea & . & . & 16 & 7 & 4 & . & 20 & 30 \\
\hline Silene supina & 7 & . & . & . & . & . & 5 & 30 \\
\hline Galatella villosa & . & . & 4 & . & 8 & . & 20 & 30 \\
\hline Elytrigia repens & . & . & 7 & 5 & . & 3 & 3 & 26 \\
\hline Stipa pulcherrima & . & . & 7 & 8 & 12 & . & 14 & 26 \\
\hline Asperula tephrocarpa & . & . & . & . & . & 28 & . & 39 \\
\hline Genista tinctoria agg. & 7 & . & . & . & 4 & 3 & . & 35 \\
\hline Helichrysum arenarium & . & 4 & 11 & 9 & . & . & 3 & 30 \\
\hline Onosma simplicissima & . & . & . & . & . & . & . & 39 \\
\hline Psephellus marschallianus agg. & . & . & 9 & 3 & . & . & 27 & 26 \\
\hline \multicolumn{9}{|l|}{ Festuco-Brometea class } \\
\hline Bupleurum falcatum & . & 15 & 58 & 16 & . & 28 & 1 & 26 \\
\hline Campanula sibirica & 7 & . & 51 & 21 & 15 & 36 & 16 & 57 \\
\hline Carex humilis & 29 & . & 53 & 25 & . & 97 & 3 & 70 \\
\hline Festuca valesiaca agg. & . & 2 & 31 & 66 & 73 & 69 & 51 & 74 \\
\hline Jurinea mollis agg. & . & . & 31 & 8 & . & . & 31 & 30 \\
\hline Linum tenuifolium & . & . & 38 & . & 46 & 25 & 27 & 4 \\
\hline Medicago falcata agg. & . & 23 & 47 & 36 & 31 & 19 & 21 & 52 \\
\hline Pimpinella tragium agg. & . & . & . & . & 42 & 44 & 22 & 52 \\
\hline Scabiosa ochroleuca & . & 64 & 56 & 35 & . & . & 2 & 9 \\
\hline Securigera varia & . & 32 & 29 & 17 & 4 & 3 & 5 & 57 \\
\hline Stachys recta & 21 & 21 & 38 & 32 & 23 & . & 20 & 57 \\
\hline Stipa capillata & . & . & 42 & 23 & 31 & . & 34 & 61 \\
\hline Teucrium polium & . & . & 13 & 2 & 81 & 3 & 65 & 91 \\
\hline Teucrium chamaedrys & 71 & . & 80 & 38 & 62 & 58 & 31 & . \\
\hline Teucrium montanum agg. & . & 26 & 44 & 37 & . & 83 & 4 & . \\
\hline Vincetoxicum hirundinaria & 64 & 66 & 27 & 6 & 4 & 8 & 10 & 74 \\
\hline \multicolumn{9}{|c|}{ Other species with low frequency } \\
\hline Cystopteris fragilis & 21 & 4 & . & 1 & . & . & . & . \\
\hline Digitalis grandiflora & 21 & 13 & . & 1 & . & . & . & . \\
\hline Geranium robertianum & 14 & 21 & . & 1 & . & . & . & . \\
\hline Viola rupestris & . & 21 & . & . & . & . & . & . \\
\hline Hieracium murorum & . & 21 & . & . & . & . & . & . \\
\hline Viola hirta & . & 21 & 18 & 2 & . & . & 2 & . \\
\hline Erysimum witmannii & . & 19 & . & . & . & . & . & . \\
\hline Viola tricolor agg. & . & 19 & . & 1 & . & . & . & . \\
\hline Campanula rapunculoides & . & 19 & . & 2 & . & . & . & . \\
\hline Teucrium botrys & . & 17 & . & . & . & . & . & . \\
\hline Chrysanthemum zawadskii & . & 17 & . & . & . & . & . & . \\
\hline Aster alpinus & . & 17 & . & . & . & . & . & . \\
\hline Cerastium arvense & . & 17 & . & 2 & . & . & . & . \\
\hline Ajuga genevensis & . & 19 & 4 & . & . & . & . & . \\
\hline Dianthus carthusianorum agg. & 7 & 17 & . & 1 & . & . & . & . \\
\hline Phleum phleoides & . & 19 & 2 & . & 8 & 3 & . & . \\
\hline Arabidopsis arenosa & 7 & 17 & . & 14 & . & . & . & . \\
\hline Pilosella echioides & . & . & 24 & 9 & 8 & . & 2 & 4 \\
\hline Seseli rigidum agg. & . & . & 22 & 1 & . & . & 8 & . \\
\hline
\end{tabular}




\begin{tabular}{|c|c|c|c|c|c|c|c|c|}
\hline No. of relevés & 14 & 47 & 45 & 173 & 26 & 36 & 124 & 23 \\
\hline Linaria genistifolia & . & . & 22 & 22 & 4 & . & 7 & 4 \\
\hline Plantago media & . & 9 & 22 & 5 & . & . & 5 & 22 \\
\hline Cytisus ruthenicus & . & . & 20 & 1 & 12 & . & 3 & 4 \\
\hline Cytisus austriacus & . & . & 18 & 2 & . & . & 3 & . \\
\hline Asyneuma canescens & . & . & 18 & 3 & . & . & 2 & . \\
\hline Echinops ritro subsp. ruthenicus & . & . & 18 & . & . & . & 3 & . \\
\hline Fragaria viridis & 7 & 2 & 18 & 3 & . & . & . & . \\
\hline Salvia pratensis & . & 4 & 18 & 8 & . & . & 1 & . \\
\hline Salvia pratensis & . & 4 & 18 & 8 & . & . & 1 & . \\
\hline Melampyrum arvense agg. & . & . & 18 & 12 & 4 & 3 & . & 4 \\
\hline Helictotrichon desertorum & & & 16 & & & & & \\
\hline Peucedanum cervaria & . & . & 16 & 1 & . & . & . & . \\
\hline Centaurea orientalis & . & . & 16 & 2 & 12 & . & 3 & 9 \\
\hline Cleistogenes serotina agg. & . & . & 9 & 24 & 19 & . & 22 & . \\
\hline Lappula squarrosa & . & . & . & 24 & 4 & . & 1 & . \\
\hline Seseli hippomarathrum & . & . & . & 22 & . & . & . & . \\
\hline Silene eugeniae & . & . & . & 21 & . & . & . & . \\
\hline Allium podolicum & . & . & . & 21 & . & . & . & . \\
\hline Aurinia saxatilis & . & 9 & . & 21 & . & . & . & . \\
\hline Melilotus officinalis & . & . & 4 & 17 & . & . & . & . \\
\hline Agropyron cristatum agg. & . & . & . & 16 & 23 & 11 & 15 & . \\
\hline Salvia scabiosifolia & . & . & . & . & 23 & . & . & . \\
\hline Scabiosa columbaria & . & . & . & 1 & 23 & 6 & . & . \\
\hline Cephalaria coriacea & . & . & . & . & 23 & 8 & 2 & . \\
\hline Erysimum cuspidatum & . & . & . & . & 23 & 19 & . & . \\
\hline Paeonia tenuifolia & . & . & . & . & 19 & . & . & . \\
\hline Inula oculus-christi & . & . & . & . & 19 & . & 2 & . \\
\hline Ajuga chamaepytis agg. & . & . & . & 5 & 19 & . & 9 & 17 \\
\hline Sideritis montana agg. & . & . & 4 & 14 & 19 & . & 10 & . \\
\hline Hypericum tauricum & . & . & . & . & . & 22 & . & . \\
\hline Galium verum & . & . & 7 & 9 & 8 & 22 & 7 & . \\
\hline Ranunculus breyninus agg. & . & . & 9 & . & . & 17 & . & . \\
\hline Haplophyllum suaveolens & . & . & . & . & 8 & . & 20 & . \\
\hline Onosma visianii & . & . & 2 & . & . & . & 20 & . \\
\hline Astragalus vesicarius & . & . & . & . & . & . & 20 & 17 \\
\hline Tanacetum millefolium & . & . & . & . & . & . & 16 & . \\
\hline Dianthus pseudoarmeria & . & . & . & . & 8 & . & 18 & . \\
\hline Ephedra distachya & . & . & . & 2 & 8 & . & 12 & . \\
\hline Convolvulus lineatus & . & . & . & . & 8 & . & 15 & . \\
\hline Oxytropis pilosa & . & . & . & 1 & 4 & . & 3 & 22 \\
\hline Carex pediformis & . & . & . & . & . & . & . & 22 \\
\hline Hypericum elegans & . & . & 4 & 5 & . & . & 7 & 17 \\
\hline \multicolumn{9}{|l|}{ Shrubs } \\
\hline Cornus mas (juv.) & 21 & . & 7 & . & . & . & . & . \\
\hline Cotinus coggygria & 43 & . & 16 & . & 4 & . & 4 & . \\
\hline Cotoneaster integerrimus agg. & 36 & 11 & . & 6 & . & 11 & . & . \\
\hline Spiraea media & 71 & . & . & . & . & . & . & . \\
\hline
\end{tabular}


Appendix 1: The list of aggregate species. Original names of the species are provided according to the Mosyakin \& Fedoronchuk (1999)

Achillea millefolium agg.: Achillea collina, Achillea millefolium, Achillea pannonica, Achillea setacea, Achillea submillefolium. Agropyron cristatum agg.: Agropyron cristatum, Agropyron pectinatum.

Ajuga chamaepytis agg.: Ajuga chamaepitys, Ajuga chia.

Allium angulosum agg.: Allium angulosum, Allium flavescens.

Allium paniculatum agg.: Allium paniculatum, Allium rupestre.

Androsace villosa agg.: Androsace koso-poljanskii, Androsace taurica.

Odontarrhena tortuosa agg.: Alyssum gymnopodum, Alyssum tortuosum.

Anthyllis vulneraria agg.: Anthyllis biebersteiniana, Anthyllis macrocephala, Anthyllis taurica.

Arenaria serpyllifolia agg.: Arenaria leptoclados, Arenaria serpyllifolia.

Artemisia campestris agg.: Artemisia campestris, Artemisia marschalliana.

Asparagus officinalis agg.: Asparagus officinalis, Asparagus polyphyllus.

Centaurea stoebe agg.: Centaurea biebersteinii, Centaurea pseudomaculosa, Centaurea stoebe.

Psephellus marschallianus agg.: Centaurea carbonata, Centaurea marschalliana.

Cytisus hirsutus agg.: Chamaecytisus polytrichus, Chamaecytisus supinus.

Cleistogenes serotina agg.: Cleistogenes bulgarica, Cleistogenes serotina.

Cotoneaster integerrimus agg.: Cotoneaster integerrimus, Cotoneaster melanocarpus.

Dianthus carthusianorum agg.: Dianthus carpaticus, Dianthus carthusianorum.

Crataegus monogyna agg.: Crataegus leiomonogyna, Crataegus monogyna, Crataegus praearmata.

Elytrigia intermedia agg.: Elytrigia intermedia, Elytrigia trichophora.

Brassica elongata agg.: Erucastrum armoracioides, Erucastrum cretaceum.

Euphorbia petrophila agg.: Euphorbia cretophila, Euphorbia petrophila.

Euphorbia nicaeensis agg.: Euphorbia glareosa, Euphorbia stepposa.

Euphrasia stricta agg.: Euphrasia stricta, Euphrasia pectinata.

Festuca valesiaca agg.: Festuca pseudodalmatica, Festuca pseudovina, Festuca rupicola, Festuca saxatilis, Festuca valesiaca.

Genista tinctoria agg.: Genista depressa, Genista tinctoria.

Helianthemum nummularium agg.: Helianthemum chamaecystus, Helianthemum nummularium subsp. obscurum,

Helianthemum nummularium.

Iris aphylla agg.: Iris aphylla, Iris hungarica.

Jovibarba globifera agg.: Jovibarba globifera, Jovibarba hirta subsp. glabrescens, Jovibarba sobolifera.

Jurinea mollis agg.: Jurinea arachnoidea, Jurinea calcarea, Jurinea mollissima.

Jurinea stoechadifolia agg.: Jurinea brachycephala, Jurinea stoechadifolia.

Koeleria brevis agg.: Koeleria brevis, Koeleria lobata.

Linum austriacum agg.: Linum austriacum, Linum marschallianum.

Linum flavum agg.: Linum basarabicum, Linum czerniaevii, Linum flavum.

Linum hirsutum agg.: Linum hirsutum, Linum lanuginosum.

Marrubium peregrinum agg.: Marrubium peregrinum, Marrubium praecox.

Medicago falcata agg.: Medicago glutinosa, Medicago romanica, Medicago sativa subsp. falcata.

Melampyrum arvense agg.: Melampyrum argyrocomum, Melampyrum arvense.

Minuartia setacea agg.: Minuartia aucta, Minuartia euxina, Minuartia leiosperma, Minuartia thyraica.

Nonea pulla agg.: Nonea pulla, Nonea rossica.

Onobrychis arenaria agg.: Onobrychis arenaria, Onobrychis miniata.

Ononis spinosa agg.: Ononis arvensis, Ononis spinosa.

Peucedanum alsaticum agg.: Peucedanum alsaticum, Peucedanum lubimenkoanum.

Peucedanum ruthenicum agg.: Peucedanum ruthenicum, Peucedanum tauricum.

Phlomis herba-venti agg.: Phlomis pungens, Phlomis taurica.

Pimpinella tragium agg.: Pimpinella lithophila, Pimpinella titanophila.

Polygala comosa agg.: Polygala comosa, Polygala podolica.

Potentilla astracanica agg.: Potentilla astracanica, Potentilla callieri.

Potentilla recta agg.: Potentilla obscura, Potentilla pilosa, Potentilla recta. 
Sanguisorba minor agg.: Poterium polygamum, Poterium sanguisorba.

Prunus spinosa agg.: Prunus spinosa, Prunus stepposa.

Pyrus communis agg.: Pyrus communis, Pyrus pyraster.

Ranunculus breyninus agg.: Ranunculus oreophilus, Ranunculus zapalowiczii.

Salvia nemorosa agg.: Salvia nemorosa, Salvia tesquicola.

Draba podolica agg.: Schivereckia mutabilis, Schivereckia podolica.

Scorzonera hispanica agg.: Scorzonera hispanica, Scorzonera stricta.

Tephroseris integrifolia agg.: Senecio integrifolius, Senecio jailicola.

Seseli rigidum agg.: Seseli peucedanifolium, Seseli tortuosum.

Sideritis montana agg.: Sideritis montana, Sideritis comosa.

Silene nutans agg.: Silene dubia, Silene italica subsp. nemoralis, Silene nutans.

Teucrium montanum agg.: Teucrium jailae, Teucrium montanum, Teucrium pannonicum.

Thymus dimorphus agg.: Thymus dimorphus, Thymus roegneri.

Thymus pannonicus agg.: Thymus marschallianus, Thymus pannonicus.

Valeriana stolonifera agg.: Valeriana officinalis, Valeriana stolonifera.

Valerianella dentata agg.: Valerianella dentata, Valerianella mixta.

Veronica austriaca agg.: Veronica austriaca, Veronica jacquinii, Veronica teucrium.

Veronica verna agg.: Veronica dillenii, Veronica verna.

Veronica spicata agg.: Veronica incana, Veronica spicata.

Viola tricolor agg.: Viola matutina, Viola tricolor

Appendix 2: The Tukey's HSD post hoc results

\begin{tabular}{|c|c|c|c|c|c|c|c|c|c|c|c|c|}
\hline Syntaxa ID & $\mathrm{Hd}$ & $\mathrm{fH}$ & Rc & $\mathrm{Sl}$ & $\mathrm{Ca}$ & $\mathrm{Nt}$ & $\mathrm{Ae}$ & $\mathrm{Tm}$ & $\mathrm{Om}$ & Kn & $\mathrm{Cr}$ & $\mathrm{Lc}$ \\
\hline $1-2$ & 0.861 & $0.1 * 10^{-4}$ & 0.777 & $0.6^{*} 10^{-2}$ & $0.1^{*} 10^{-4}$ & 0.017 & 0.999 & $0.1^{*} 10^{-4}$ & $0.8^{*} 10^{-4}$ & 0.989 & 0.026 & $0.2^{*} 10^{-3}$ \\
\hline $1-3$ & $0.1 * 10^{-4}$ & $0.1^{*} 10^{-4}$ & $0.1^{*} 10^{-4}$ & $0.1^{*} 10^{-4}$ & 0.999 & 1.000 & 0.935 & 0.693 & $0.1^{*} 10^{-4}$ & $0.1^{*} 10^{-4}$ & 0.807 & $0.1^{*} 10^{-4}$ \\
\hline $1-4$ & $0.1^{*} 10^{-4}$ & $0.1^{*} 10^{-4}$ & $0.1^{*} 10^{-4}$ & $0.1^{*} 10^{-4}$ & $0.6^{*} 10^{-4}$ & 0.988 & 0.061 & 1.000 & $0.1^{*} 10^{-3}$ & $0.1^{*} 10^{-4}$ & 0.553 & $0.1^{*} 10^{-4}$ \\
\hline $1-5$ & $0.1^{*} 10^{-4}$ & 0.971 & $0.1^{*} 10^{-4}$ & $0.1^{*} 10^{-4}$ & $0.8^{*} 10^{-3}$ & 0.332 & $0.1^{*} 10^{-3}$ & $0.1^{*} 10^{-4}$ & $0.1^{*} 10^{-4}$ & $0.1^{*} 10^{-4}$ & $0.1^{*} 10^{-4}$ & $0.1^{*} 10^{-4}$ \\
\hline $1-6$ & $0.1^{*} 10^{-4}$ & 0.862 & $0.1^{*} 10^{-4}$ & $0.1^{*} 10^{-4}$ & $0.1^{*} 10^{-4}$ & 0.658 & 0.039 & $0.1 * 10^{-4}$ & $0.1^{*} 10^{-4}$ & $0.7^{*} 10^{-2}$ & $0.8^{*} 10^{-3}$ & $0.1^{*} 10^{-4}$ \\
\hline $1-7$ & $0.1^{*} 10^{-4}$ & $0.1^{*} 10^{-4}$ & $0.1^{*} 10^{-4}$ & $0.1^{*} 10^{-4}$ & 1.000 & 0.585 & 0.415 & $0.1^{*} 10^{-4}$ & $0.1^{*} 10^{-4}$ & $0.1^{*} 10^{-4}$ & 0.999 & $0.1^{*} 10^{-4}$ \\
\hline $1-8$ & $0.1^{*} 10^{-4}$ & $0.1^{*} 10^{-4}$ & $0.1^{*} 10^{-4}$ & $0.1^{*} 10^{-4}$ & 0.999 & 0.999 & 0.998 & 1.000 & $0.1^{*} 10^{-4}$ & $0.1^{*} 10^{-4}$ & $0.1^{*} 10^{-4}$ & $0.1^{*} 10^{-4}$ \\
\hline $2-3$ & $0.1^{*} 10^{-4}$ & 0.999 & $0.1^{*} 10^{-4}$ & $0.1^{*} 10^{-4}$ & $0.1^{*} 10^{-4}$ & $0.5^{*} 10^{-4}$ & 0.194 & $0.1^{*} 10^{-4}$ & $0.1^{*} 10^{-4}$ & $0.1^{*} 10^{-4}$ & 0.394 & 0.021 \\
\hline $2-4$ & $0.1^{*} 10^{-4}$ & $0.1^{*} 10^{-4}$ & $0.1^{*} 10^{-4}$ & $0.1^{*} 10^{-4}$ & $0.1^{*} 10^{-4}$ & $0.2^{*} 10^{-3}$ & $0.1^{*} 10^{-2}$ & $0.1^{*} 10^{-4}$ & $0.1^{*} 10^{-4}$ & $0.1^{*} 10^{-4}$ & 0.178 & $0.1^{*} 10^{-4}$ \\
\hline $2-5$ & $0.1^{*} 10^{-4}$ & $0.1^{*} 10^{-4}$ & $0.1^{*} 10^{-4}$ & $0.1^{*} 10^{-4}$ & $0.1^{*} 10^{-4}$ & 0.990 & $0.1^{*} 10^{-4}$ & $0.1^{*} 10^{-4}$ & $0.1^{*} 10^{-4}$ & $0.1^{*} 10^{-4}$ & $0.1^{*} 10^{-4}$ & $0.1^{*} 10^{-4}$ \\
\hline $2-6$ & $0.1^{*} 10^{-4}$ & $0.1^{*} 10^{-4}$ & $0.1^{*} 10^{-4}$ & $0.1^{*} 10^{-4}$ & $0.1^{*} 10^{-4}$ & 0.569 & $0.7^{*} 10^{-2}$ & $0.1^{*} 10^{-4}$ & $0.1 * 10^{-4}$ & $0.1^{*} 10^{-4}$ & $0.1^{*} 10^{-4}$ & $0.1^{*} 10^{-4}$ \\
\hline $2-7$ & $0.1^{*} 10^{-4}$ & $0.1^{*} 10^{-4}$ & $0.1^{*} 10^{-4}$ & $0.1^{*} 10^{-4}$ & $0.1^{*} 10^{-4}$ & 0.128 & & $0.1^{*} 10^{-4}$ & $0.1^{*} 10^{-4}$ & $0.1^{*} 10^{-4}$ & $0.4^{*} 10^{-4}$ & $0.1^{*} 10^{-4}$ \\
\hline $2-8$ & $0.1^{*} 10^{-4}$ & 0.054 & $0.1 * 10^{-4}$ & $0.1^{*} 10^{-4}$ & $0.1^{*} 10^{-4}$ & $0.2^{*} 10^{-3}$ & 0.999 & $0.1^{*} 10^{-4}$ & $0.1^{*} 10^{-4}$ & $0.1^{*} 10^{-4}$ & $0.1^{*} 10^{-4}$ & $0.1^{*} 10^{-4}$ \\
\hline $3-4$ & 0.852 & $0.1 * 10^{-4}$ & $0.1^{*} 10^{-2}$ & 0.023 & $0.1^{*} 10^{-4}$ & 0.797 & $0.1^{*} 10^{-4}$ & 0.025 & 0.324 & 0.135 & 1.000 & 0.014 \\
\hline $3-5$ & $0.1^{*} 10^{-4}$ & $0.1 * 10^{-4}$ & $0.1^{*} 10^{-4}$ & $0.1^{*} 10^{-4}$ & $0.1^{*} 10^{-4}$ & 0.059 & $0.1 * 10^{-4}$ & $0.1 * 10^{-4}$ & $0.1^{*} 10^{-4}$ & 0.892 & $0.1^{*} 10^{-4}$ & $0.1^{*} 10^{-4}$ \\
\hline $3-6$ & 0.464 & & $0.1^{*} 10^{-4}$ & & $0.1^{*} 10^{-4}$ & 0.205 & $0.1^{*} 10^{-4}$ & & & & $0.1^{*} 10^{-4}$ & $0.1^{*} 10^{-4}$ \\
\hline $3-7$ & $0.1^{*} 10^{-4}$ & $0.1 * 10^{-4}$ & $0.3^{*} 10^{-2}$ & $0.1^{*} 10^{-4}$ & 0.888 & 0.057 & $0.1 * 10^{-4}$ & $0.1 * 10^{-4}$ & $0.1 * 10^{-4}$ & $0.1^{*} 10^{-4}$ & 0.587 & $0.1^{*} 10^{-4}$ \\
\hline $3-8$ & $0.1 * 10^{-4}$ & $0.1^{*} 10^{-4}$ & 0.287 & $0.1 * 10^{-4}$ & 0.763 & 0.999 & 0.168 & 0.723 & $0.1 * 10^{-4}$ & $0.1^{*} 10^{-4}$ & $0.1^{*} 10^{-4}$ & $0.1^{*} 10^{-4}$ \\
\hline $4-5$ & $0.1 * 10^{-4}$ & $0.1^{*} 10^{-4}$ & $0.3^{*} 10^{-2}$ & $0.1^{*} 10^{-4}$ & $0.1^{*} 10^{-4}$ & 0.375 & 0.035 & $0.1 * 10^{-4}$ & $0.1 * 10^{-4}$ & $0.2^{*} 10^{-2}$ & $0.1^{*} 10^{-4}$ & $0.1^{*} 10^{-4}$ \\
\hline $4-6$ & 0.969 & $0.1^{*} 10^{-4}$ & $0.1^{*} 10^{-4}$ & $0.1^{*} 10^{-4}$ & $0.1^{*} 10^{-4}$ & 0.810 & 0.995 & $0.1^{*} 10^{-4}$ & & $0.7^{*} 10^{-2}$ & $0.1^{*} 10^{-4}$ & $0.1^{*} 10^{-4}$ \\
\hline $4-7$ & $0.1^{*} 10^{-4}$ & $0.1 * 10^{-4}$ & $0.1^{*} 10^{-4}$ & $0.1^{*} 10^{-4}$ & $0.1^{*} 10^{-4}$ & 0.391 & 0.749 & $0.1 * 10^{-4}$ & $0.1^{*} 10^{-4}$ & $0.1^{*} 10^{-4}$ & 0.014 & $0.1^{*} 10^{-4}$ \\
\hline $4-8$ & $0.1^{*} 10^{-4}$ & $0.1^{*} 10^{-4}$ & $0.1^{*} 10^{-4}$ & $0.1^{*} 10^{-4}$ & $0.1^{*} 10^{-4}$ & 0.676 & 0.225 & 0.999 & $0.1^{*} 10^{-4}$ & $0.1^{*} 10^{-4}$ & $0.1^{*} 10^{-4}$ & $0.2^{*} 10^{-3}$ \\
\hline $5-6$ & $0.1 * 10^{-4}$ & 0.999 & 0.513 & $0.2^{*} 10^{-4}$ & 0.960 & 0.999 & 0.641 & $0.1 * 10^{-4}$ & $0.1 * 10^{-4}$ & $0.1 * 10^{-4}$ & 0.420 & $0.1^{*} 10^{-2}$ \\
\hline $5-7$ & 0.999 & $0.1 * 10^{-4}$ & 0.101 & 0.999 & $0.1 * 10^{-4}$ & 0.989 & $0.1 * 10^{-2}$ & $0.1 * 10^{-4}$ & 0.831 & $0.1^{*} 10^{-4}$ & $0.1^{*} 10^{-4}$ & 0.993 \\
\hline $5-8$ & 0.435 & $0.1 * 10^{-4}$ & 0.286 & 0.311 & $0.1 * 10^{-2}$ & 0.049 & $0.4^{*} 10^{-3}$ & $0.1 * 10^{-4}$ & 0.999 & $0.1 * 10^{-4}$ & $0.1^{*} 10^{-4}$ & $0.2^{*} 10^{-4}$ \\
\hline $6-7$ & $0.1^{*} 10^{-4}$ & $0.1 * 10^{-4}$ & $0.1^{*} 10^{-4}$ & $0.1^{*} 10^{-4}$ & $0.1 * 10^{-4}$ & 1.000 & 0.621 & 0.454 & $0.1 * 10^{-4}$ & $0.1^{*} 10^{-4}$ & $0.1^{*} 10^{-4}$ & $0.4^{*} 10^{-3}$ \\
\hline $6-8$ & 0.001 & $0.1 * 10^{-4}$ & $0.1^{*} 10^{-3}$ & 0.432 & $0.1^{*} 10^{-4}$ & 0.166 & 0.155 & $0.1 * 10^{-4}$ & $0.1 * 10^{-4}$ & $0.1^{*} 10^{-4}$ & $0.1^{*} 10^{-4}$ & 0.813 \\
\hline $7-8$ & 0.023 & 0.997 & 0.999 & 0.021 & 0.998 & 0.072 & 0.874 & $0.1^{*} 10^{-4}$ & 0.999 & 0.566 & $0.1^{*} 10^{-4}$ & $0.1^{*} 10^{-4}$ \\
\hline
\end{tabular}

